\title{
Differential Response of Two Tomato Genotypes, Wild Type cv. Ailsa Craig and Its ABA-Deficient Mutant flacca to Short-Termed Drought Cycles
}

\author{
Bojana Živanović $^{1}{ }^{\circledR}$, Sonja Milić Komić ${ }^{1}$, Nenad Nikolić ${ }^{1}$, Dragosav Mutavdžić $^{1,2}$, Tatjana Srećković ${ }^{1,2}{ }^{\circledR}$, \\ Sonja Veljović Jovanović ${ }^{1,2, *}$ and Ljiljana Prokić ${ }^{3, *}$ (i)
}

1 Institute for Multidisciplinary Research, University of Belgrade, Kneza Višeslava 1, 11030 Belgrade, Serbia; bojana.zivanovic@imsi.rs (B.Ž.); sonjamilic@imsi.rs (S.M.K.); nnikolic@imsi.bg.ac.rs (N.N.); gane@imsi.rs (D.M.); tatjanas@rcub.bg.ac.rs (T.S.)

2 Center for Green Technologies, Institute for Multidisciplinary Research, University of Belgrade, Kneza Višeslava 1, 11030 Belgrade, Serbia

3 Faculty of Agriculture, University of Belgrade, Nemanjina 6, 11080 Belgrade, Serbia

* Correspondence: sonjavel@imsi.rs (S.V.J.); ljprokic@agrif.bg.ac.rs (L.P.)

\section{check for}

updates

Citation: Živanović, B.; Milić Komić, S.; Nikolić, N.; Mutavdžić, D.; Srećković, T.; Veljović Jovanović, S.; Prokić, L. Differential Response of Two Tomato Genotypes, Wild Type cv. Ailsa Craig and Its ABA-Deficient Mutant flacca to Short-Termed Drought Cycles. Plants 2021, 10, 2308. https://doi.org/10.3390/ plants10112308

Academic Editor: Fulai Liu

Received: 30 September 2021

Accepted: 20 October 2021

Published: 27 October 2021

Publisher's Note: MDPI stays neutral with regard to jurisdictional claims in published maps and institutional affiliations.

Copyright: (c) 2021 by the authors. Licensee MDPI, Basel, Switzerland. This article is an open access article distributed under the terms and conditions of the Creative Commons Attribution (CC BY) license (https:/ / creativecommons.org/licenses/by/ $4.0 /)$.
Abstract: Two tomato genotypes with constitutively different ABA level, flacca mutant and wild type of Ailsa Craig cv. (WT), were subjected to three repeated drought cycles, with the aim to reveal the role of the abscisic acid (ABA) threshold in developing drought tolerance. Differential responses to drought of two genotypes were obtained: more pronounced stomatal closure, ABA biosynthesis and proline accumulation in WT compared to the mutant were compensated by dry weight accumulation accompanied by transient redox disbalance in flacca. Fourier-transform infrared (FTIR) spectra analysis of isolated cell wall material and morphological parameter measurements on tomato leaves indicated changes in dry weight accumulation and carbon re-allocation to cell wall constituents in flacca, but not in WT. A higher proportion of cellulose, pectin and lignin in isolated cell walls from flacca leaves further increased with repeated drought cycles. Different ABA-dependent stomatal closure between drought cycles implies that acquisition of stomatal sensitivity may be a part of stress memory mechanism developed under given conditions. The regulatory role of ABA in the cell wall restructuring and growth regulation under low leaf potential was discussed with emphasis on the beneficial effects of drought priming in developing differential defense strategies against drought.

Keywords: abscisic acid; drought; recovery period; cell wall constituents; stress memory; tomato mutants; stomatal sensitivity

\section{Introduction}

Water scarcity has become one of the greatest problems for agricultural production, with rapidly increasing instances in many areas of the world. Drought is identified as a major threat to crop production causing billions in annual economic losses, mainly from the agricultural sector [1,2]. The impact of drought on plants depends not only on the genotypes, the developmental progression of specific tissues and of the whole plant system but also on the duration, frequency and intensity of drought, as well as the presence of other abiotic stresses, such as high temperature, sunlight intensity or UV radiation [3-5]. Plants respond to drought through morphological, physiological and biochemical modulations controlled at the molecular level by hormones, sugars, proline and reactive oxygen species (ROS) via a complex network, i.e., different signaling pathways leading to a regulated gene expression [6-11]. Plants eliminate elevated ROS by an efficient antioxidative defense system consisting of the enzymatic and non-enzymatic antioxidants [12,13]. Maintenance of the ascorbate redox state is important for plants' homeostasis under water deprivation [14]. Furthermore, plant cell wall composition and integrity plays an important role in abiotic stress tolerance and is one of the important traits in the selection of drought tolerant 
varieties $[15,16]$.The drought and salt-induced perturbation of the cell wall, which modifies its components' synthesis, are well documented [17-19].

Stress imprinting (or priming), which positively affects plant survival under repetitive stresses, is widely accepted as an alternative agriculture measure to prepare plants to withstand drought episodes accompanied with high insolation and heat waves [20,21]. Previous studies have shown that plants pre-exposed to multiple drought stress episodes exhibit rapid and more efficient responses compared to plants that experience drought for the first time [21-23]. Drought priming can reset plant metabolism leading to changes in primary and secondary metabolism, forming a short term memory based on the accumulation of carbohydrates, amino acids [24] and antioxidants [25].

Tomatoes (Lycopersicon esculentum Mill.) are one of the most important and widely grown vegetables in the world, especially in the Mediterranean region [26,27]. Its high nutritional value is based on a high content of phytonutrients, such as phenolic compounds and carotenoids [28]. Due to its short lifecycle and relatively small genome, the tomato is an excellent fleshy fruit model system [29]. Tomato plants are very sensitive to drought, which is a consequence of their limited tolerance against this stress [30]. The proteomic analyses of tomato plants exposed to drought and their recovery period have identified numerous drought responsive proteins involved in the antioxidative defense $(\mathrm{Cu} / \mathrm{Zn}$ superoxide dismutase, catalase, ascorbate peroxidase), photosynthetic metabolism, electron transport (NADP reductase), protein biosynthesis and cell wall metabolism [29-31]. It was shown by using gene ontology enrichment analyses that drought affects the regulation of histone encoding genes, chlorophyll binding, heat shock proteins and genes that are related to protein products involved in the cell wall and sugar metabolism, as well as ABA-controlled chloroplast to nucleus signaling $[29,32]$.

Abscisic acid (ABA) is a key molecule that underpins the regulatory mechanisms of a plant's response to drought, such as the regulation of the turgor pressure of guard cells and stomatal closure, maintenance of water balance, osmotic stress tolerance and activity of antioxidative enzymes [33-35]. In plants exposed to progressive soil drying, significant changes in ABA and/or leaf water potential ( $\Psi)$, as chemical and hydraulic signals, are responsible for stomatal closure, implying their mutual interaction in the regulation of the stomatal aperture [36,37]. Turgor changes and stomatal closure under stress conditions can also occur due to modulation of the elastic properties of the cell wall and the activity status of the anion channels in guard cells [38].

Recent studies have demonstrated that ABA may contribute to increased drought tolerance related to drought memory effect $[39,40]$. The stomata of plants, which have once been exposed to drought stress, may also remain partially closed during the recovery period. Thus, partially closed stomatal contribute to the reduction in water loss during subsequent drought episodes [22]. Stomatal closure is associated with increased ABA content and ABA-related genes expression, which are key modulators of ABA-biosynthetic and catabolic pathways [41].

Elevated ABA content under drought is predominantly the result of de novo biosynthesis of genes included in ABA metabolism, such as 9-cis-epoxycarotenoid dioxygenase (NCEDs) [42,43]. Moreover, it can also be the result of the decreased ABA catabolism [42] and/or ABA redistribution induced by $\mathrm{pH}$ fluctuations [44].

In this study, we used one of the tomato (Ailsa Craig cv.) ABA-deficient mutants, flacca, which, compared to wild type, accumulates a lower content of ABA [45].The last step in $\mathrm{ABA}$ biosynthesis involves the oxidation of abscisic aldehyde to ABA by the molybdenum containing aldehyde oxidase (AO; EC 1.2.3.1). In flacca, due to the deletion of six base pairs in a molybdenumcofactor (Mo-Co) sulfurase, sulphuration of Mo-Co in AO is inhibited and, therefore, their oxidative activity is suppressed [45,46]. These ABA-deficient mutants wilt faster due to their higher transpiration rates and abnormal stomatal behavior, possess a reduced leaf area, thinner stem, more expressed epinasty and diminished aerial root formation [46-50]. Interestingly, upon treatment with exogenously applied ABA the mutant plants' phenotype characteristics were reversed to wild type [47-49]. 
In this work, we compare a plant's response to repeated drought cycles (watered/droughtinduced/re-watered plant status) during the vegetative development of two tomato genotypes, differing in the constitutive leaf ABA level, with the final aim to explore the ABA role in short term stress memory and acclimative mechanisms to water deficit. Recently, we reported that the same flacca mutant exhibited constitutively higher levels of soluble sugars and free amino acids (AAs) compared with its parent line Ailsa Craig cv. [51]. Here, we analyze the drought effects on plants by imposing more natural conditions on our model system that would allow maximal photosynthetic rates and faster growth. Furthermore, comparison of the molecular and physiological processes induced by repeated cycles of moderate drought might contribute to elucidation of the underlying mechanisms of plant stress memories and drought tolerance. We also compared a plant's status following prolonged recovery after one drought cycle with recovery after three repeated drought cycles in order to determine whether different patterns of drought tolerance emerge. Additionally, an understanding of the genotype-specific molecular basis of acclimatization response to drought could help us to induce specific traits in plants during the growing season, which could be beneficial under subsequent drought.

\section{Results}

2.1. Drought Cycles

\subsubsection{ABA Content, Stomata and Water Status}

Leaf ABA content in both genotypes did not vary throughout the growth period under well watered conditions, with 20-30\% less ABA concentration in the ABA-deficient mutant of Ailsa Craig, flacca, compared to its parent line (Figure 1, Supplementary Table S1, genotype effect $p=0.000000)$. Water withdrawal to the same soil water content (SWC) during 6 days in the 1st drought cycle induced a $65 \%$ and $15 \%$ increase in ABA concentration, Figure 1. The next two drought cycles led to an ABA elevation of 57 and $43 \%$ in WT and 39 and $20 \%$ in flacca, respectively. In all three drought periods, ABA accumulation in flacca was similar to the values measured in turgid WT leaves. While the ABA content in WT bounced back after three days of rehydration to levels found prior to water scarcity in all three applied cycles; the same was obtained only in the 2nd and 3rd cycles in flacca.

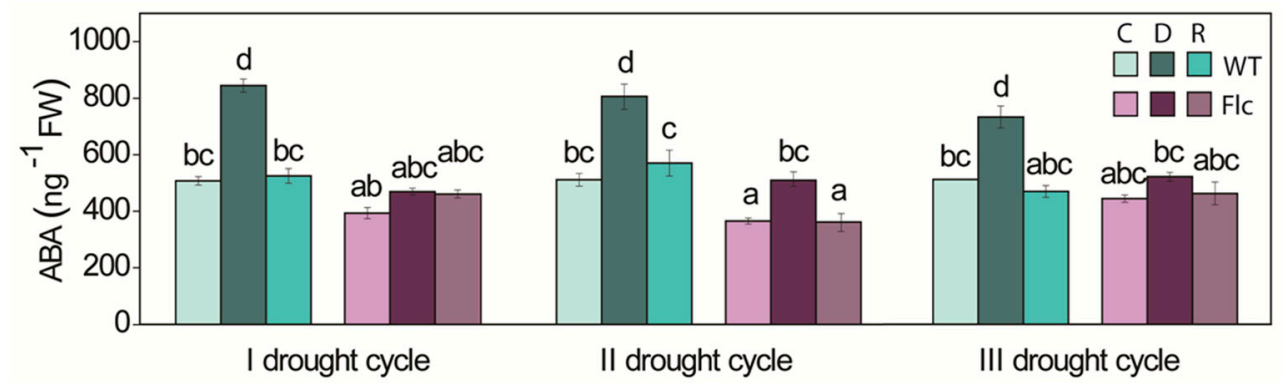

Figure 1. ABA content in the leaves of WT and flacca tomato genotypes subjected to three drought cycles (D), followed by three days of re-watering (R), with respective control plants (C). Values are presented as means \pm SE $(n \geq 7)$. Different letters denote significant differences between means according to Tukey HSD post hoc test $p \leq 0.05$.

Under optimal watering, the flacca mutant showed significantly higher stomatal conductance in comparison to WT plants throughout the whole period, with the least measured difference found in the 2nd cycle (Figure 2, Supplementary Table S1, genotype effect $p=0.000001)$. Stomatal conductance in WT drought-stressed plants varied in inverse proportion to the ABA accumulation, with the strongest response in the 3rd cycle. However, a statistically significant, but much smaller decrease compared to WT in the stomatal conductance, was also observed in flacca in the 2nd and 3rd drought episodes (Figure 2). Furthermore, stomata were more responsive to water status upon repeated re-watering treatments: stomatal conductance was restored to control values in the 2nd and 3rd drought episodes, while in the first cycle stomata remained partly closed in both genotypes (Figure 2). 


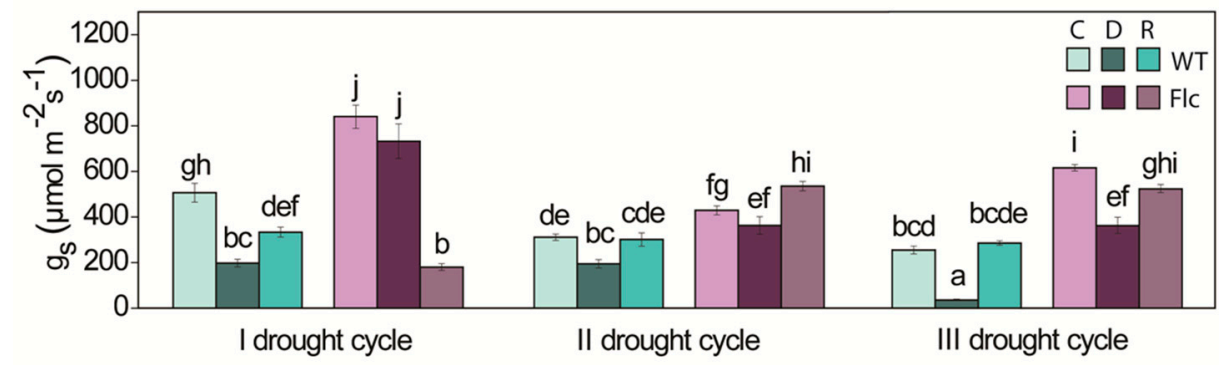

Figure 2. Stomatal conductance in the leaves of WT and flacca tomato genotypes subjected to three drought cycles (D), followed by three days of re-watering (R), with respective control plants (C). Values are presented as means $\pm \mathrm{SE}(n \geq 7)$. Different letters denote significant differences between means according to Tukey HSD post hoc test $p \leq 0.05$.

Leaf water potential $(\Psi)$ under well watered conditions did not differ between genotypes; however, in the 1st drought this decreased to a larger extent in WT than in flacca. In the next two successive drought cycles, the reduction in leaf water potential in WT was slightly smaller than in flacca. After three days of re-watering, the leaf water potential fully recovered only in the 1st drought cycle, while it partly recovered in the 2nd and 3rd cycle (Figure 3).

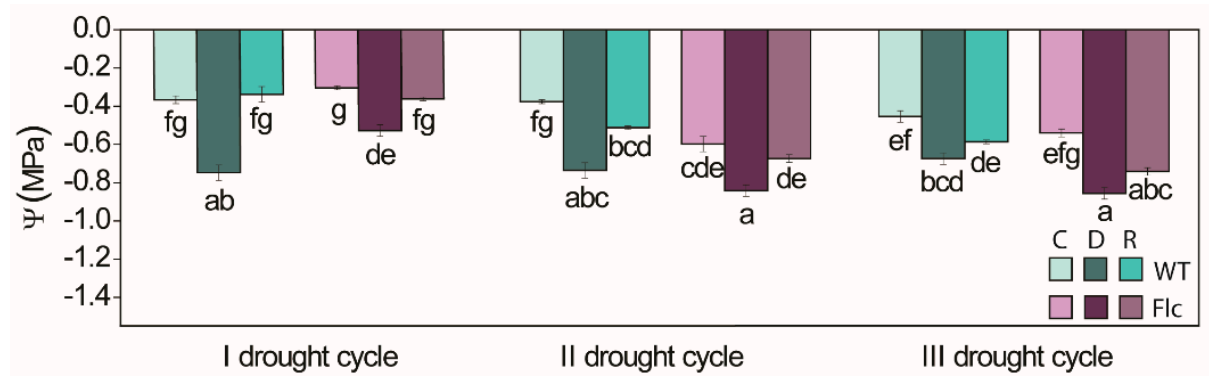

Figure 3. Leaf water potential ( $\Psi$ ) in the leaves of WT and flacca tomato genotypes subjected to three drought cycles (D), followed by three days of re-watering (R), with respective control plants (C). Values are presented as means \pm SE $(n \geq 7)$. Different letters denote significant differences between means according to Tukey HSD post hoc test $p \leq 0.05$.

\subsubsection{Drought-Induced Changes in Proline Content}

Proline accumulation, as one of the most common plant responses to water deficit, was observed in both genotypes but to a much greater extent in WT (Figure 4). In the 1st drought cycle, proline concentration in WT increased more than 25 times and in flacca more than 7 times compared to turgid leaves. An initial proline concentration was reset upon re-watering, in the 1st cycle in both genotypes and in the 2nd cycle only for WT. In the other two drought episodes, proline content did not change in comparison to respective controls (Figure 4, Supplementary Table S2). 


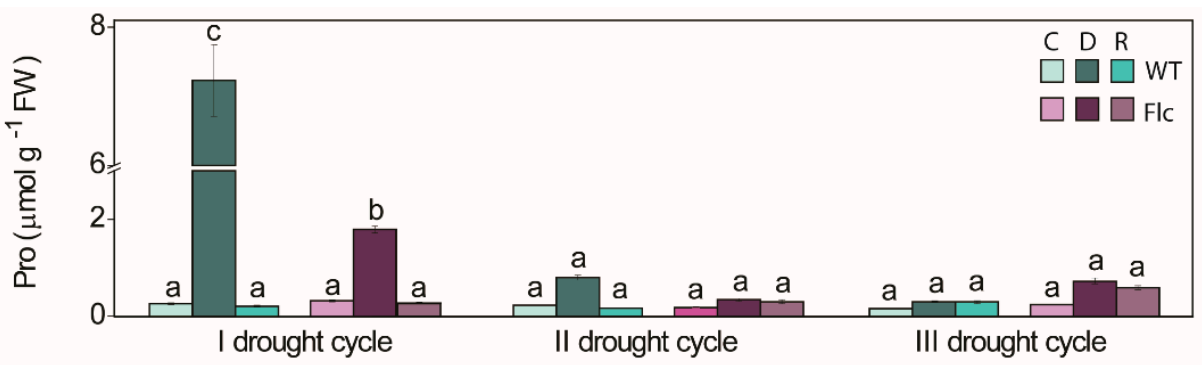

Figure 4. Proline content in the leaves of WT and flacca tomato genotypes subjected to three drought cycles (D), followed by three days of re-watering (R), with respective control plants (C). Values are presented as means $\pm \mathrm{SE}(n \geq 7)$. Different letters denote significant differences between means according to Tukey HSD post hoc test $p \leq 0.05$.

\subsubsection{Drought-Induced Changes in Ascorbate Redox State}

In all three cycles drought induced an increase in total ascorbate content only in flacca plants, while in WT it remained unchanged. In flacca, the most intensive ascorbate rise was observed in the first drought episode, which was accompanied by the most prominent decrease upon re-watering. On the other hand, in the other two cycles, re-watered plants retained total ascorbate pull similar to water-stressed plants.

Moreover, in WT plants in the recovery phase, the total ascorbate content was higher only in the 2nd cycle, while in the 1st and 3rd it was similar to control and stressed plants. The ascorbate redox state in WT plants in all drought cycles was unchanged, while in flacca plants a slight decrease in droughted plants was noticed in comparison to controls and recovered plants (Figure 5).
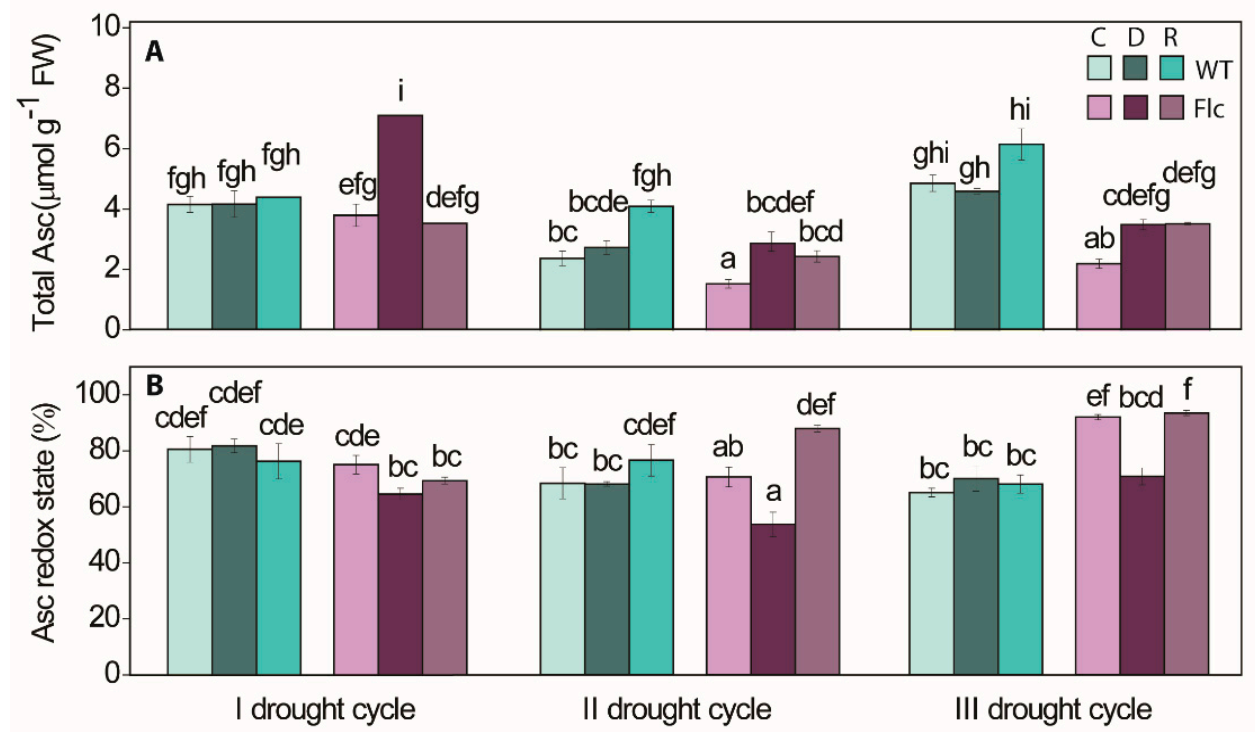

Figure 5. Total ascorbate content (A) and ascorbate redox state (B) in the leaves of WT and flacca tomato genotypes subjected to three drought cycles (D), followed by three days of re-watering (R), with respective control plants $(C)$. Values are presented as means $\pm \mathrm{SE}(n \geq 7)$. Different letters denote significant differences between means according to Tukey HSD post hoc test $p \leq 0.05$.

\subsubsection{Drought-Induced Changes in ABA-Responsive Genes Expression}

Drought treatment, in all three cycles, induced a significant increase in the expression of the NCED1 gene in both genotypes, WT and flacca, though to a larger extent in WT plants. A maximal up-regulation of NCED1 was obtained in the 3rd cycle in WT plants, reaching values four times higher than in the control from the first drought cycle. A progressive increase in the NCED1 expression after rehydration during successive drought cycles was noticed in WT but not in flacca (Figure 6). 

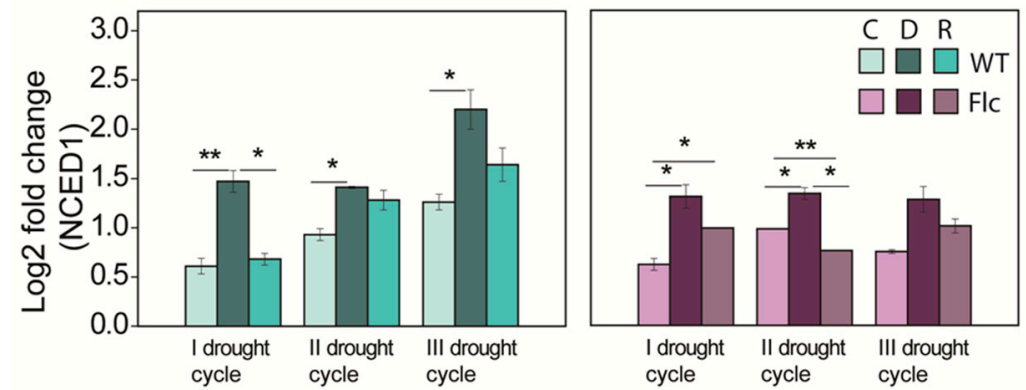

Figure 6. NCED1 expression in the leaves of WT and flacca tomato genotypes subjected to three drought cycles (D), followed by three days of re-watering (R), with respective control plants (C). Relative expression was determined by qRT PCR, and normalized to the housekeeping gene and calculated relative to WT start control. Values are presented as means $\pm \mathrm{SE}(n \geq 4)$. Asterisks denote significant differences between control, drought and recovered plants within individual genotypes in each drought cycle, according to Welch $t$-test $\left({ }^{*} p<0.05,{ }^{* *} p<0.01\right)$.

\subsection{Prolonged Recovery after First Drought and Recovery after Third Drought}

2.2.1. Effects of Prolonged Recovery after First Drought and Recovery after Third Drought on Growth Parameters in WT and flacca

To determine the effects of repeated drought episodes and prolonged recovery on plant growth, we compared growth parameters at the end of the vegetative stage in three groups of plants: (1) the control plants, which were continuously irrigated, (2) the plants that experienced one drought stress followed by 15 days period of re-watering, and (3) the plants that experienced three drought cycles.

When water deficit was imposed as an isolated event followed by 15 days of rewatering, both the leaf fresh weight and the leaf area of WT and flacca increased; however, the effect was more pronounced in the mutant (Table 1). The increase in leaf fresh weight was accompanied by a double increase in the dry weight of leaves and by a $30 \%$ decrease in SLA only in flacca. Stem dry weight was also higher by $40 \%$ at the end of experiment in flacca plants that were submitted to only one drought episode.

Table 1. Leaf, stem and total shot fresh (FW) and dry weight (DW) per plant, leaf area and specific leaf area (SLA) of WT and flacca tomato genotypes at the end of the experiment. $\mathrm{R}_{1}$ represents plants exposed to the 1 st drought cycle and then optimally watered for the next 15 days. $\mathrm{R}_{3}$ represents 3-days re-watered plants after the 3 rd drought cycle, while $\mathrm{C}$ represents respective control plants. Values are presented as means \pm SE $(n=4)$. Different letters denote significant differences between means in every genotype separately, according to Tukey HSD post hoc test $p \leq 0.05$.

\begin{tabular}{|c|c|c|c|}
\hline \multicolumn{4}{|c|}{ WT } \\
\hline & $\mathrm{C}$ & $\mathbf{R}_{\mathbf{1}}$ & $\mathbf{R}_{3}$ \\
\hline Leaves FW (g) & $31.86 \pm 0.94 b$ & $40.75 \pm 1.97 c$ & $19.89 \pm 1.63 \mathrm{a}$ \\
\hline Stem FW (g) & $26.14 \pm 0.59 \mathrm{ab}$ & $23.84 \pm 2.63 \mathrm{a}$ & $33.47 \pm 1.65 b$ \\
\hline Plant FW (g) & $58.01 \pm 1.53 \mathrm{a}$ & $64.59 \pm 4.60 \mathrm{a}$ & $53.37 \pm 3.3 \mathrm{a}$ \\
\hline Leaves DW (g) & $2.08 \pm 0.02 b$ & $2.36 \pm 0.05 c$ & $1.63 \pm 0.07 \mathrm{a}$ \\
\hline Stem DW $(\mathrm{g})$ & $2.10 \pm 0.06 \mathrm{a}$ & $2.17 \pm 0.30 \mathrm{a}$ & $1.70 \pm 0.19 a$ \\
\hline Plant DW (g) & $5.78 \pm 0.11 \mathrm{ab}$ & $6.09 \pm 0.41 b$ & $4.50 \pm 0.36 \mathrm{a}$ \\
\hline $\operatorname{LA}\left(\mathrm{cm}^{2}\right)$ & $1019.9 \pm 63.1 \mathrm{ab}$ & $1137.9 \pm 5.9 b$ & $880.8 \pm 13.9 a$ \\
\hline SLA $\left(\mathrm{cm}^{2} \mathrm{~g}^{-1} \mathrm{DW}\right)$ & $490.6 \pm 26.8 \mathrm{a}$ & $483.2 \pm 7.7 \mathrm{a}$ & $541.5 \pm 16.1 \mathrm{a}$ \\
\hline & C & $\mathrm{R}_{1}$ & $\mathrm{R}_{3}$ \\
\hline Leaves FW (g) & $27.26 \pm 0.63 a$ & $38.49 \pm 2.07 b$ & $27.08 \pm 3.69 \mathrm{a}$ \\
\hline Stem FW (g) & $15.84 \pm 0.60 b$ & $15.55 \pm 0.71 \mathrm{ab}$ & $13.01 \pm 0.50 \mathrm{a}$ \\
\hline Plant FW (g) & $43.10 \pm 0.1 \mathrm{ab}$ & $54.1 \pm 1.6 \mathrm{~b}$ & $40.1 \pm 4.2 \mathrm{a}$ \\
\hline Leaves DW (g) & $1.13 \pm 0.01 \mathrm{a}$ & $2.23 \pm 0.01 b$ & $1.97 \pm 0.16 \mathrm{~b}$ \\
\hline Stem DW $(\mathrm{g})$ & $1.05 \pm 0.02 \mathrm{a}$ & $1.56 \pm 0.01 b$ & $0.88 \pm 0.09 a$ \\
\hline
\end{tabular}


Table 1. Cont.

\begin{tabular}{cccc}
\hline Plant DW $(\mathrm{g})$ & $2.91 \pm 0.01 \mathrm{a}$ & $5.28 \pm 0.02 \mathrm{~b}$ & $4.16 \pm 0.46 \mathrm{~b}$ \\
LA $\left(\mathrm{cm}^{2}\right)$ & $630.1 \pm 3.8 \mathrm{a}$ & $963.9 \pm 8.7 \mathrm{~b}$ & $544.1 \pm 41.7 \mathrm{a}$ \\
SLA $\left(\mathrm{cm}^{2} \mathrm{~g}^{-1} \mathrm{DW}\right)$ & $557.7 \pm 3.8 \mathrm{c}$ & $433.1 \pm 3.2 \mathrm{~b}$ & $276.7 \pm 1.1 \mathrm{a}$ \\
\hline
\end{tabular}

WT plants that experienced three successive drought cycles compared with controls or $\mathrm{R}_{1}$ plants exhibited growth retardation of leaves and a slight increase in stem biomass at the end of the experiment (Table 1). On the contrary, flacca showed smaller but yet significant increases in leaf dry weight compared to $\mathrm{R}_{1}$ plants, accompanied by a decrease in leaf area and, consequently, by a decrease in SLA (Table 1).

2.2.2. Effects of Prolonged Recovery after First Drought and Recovery after Third Drought on Cell Wall Composition in WT and flacca

Overlaid WT and flacca tomato leaves' cell walls' FTIR spectra are shown in Figure 7 for the control plants, the plants after prolonged recovery and the plants after three drought cycles in the region of $800-1800 \mathrm{~cm}^{-1}$. The bands related to cellulose, such as symmetric $\mathrm{CH}_{2}$ vibration at $1436 \mathrm{~cm}^{-1}, \mathrm{CH}_{2}$ bending vibration at $1370 \mathrm{~cm}^{-1}, \mathrm{CH}_{2}$ wagging vibration at $1317 \mathrm{~cm}^{-1}, \mathrm{O}-\mathrm{C}-\mathrm{O}$ asymmetric stretching glycosidic link vibration at $1151 \mathrm{~cm}^{-1}$ and $\mathrm{C}-\mathrm{O}$ stretching vibration at $1105 \mathrm{~cm}^{-1}$ were found in all cell wall samples. The bands at $1735 \mathrm{~cm}^{-1}$ ( $\mathrm{C}=\mathrm{O}$ stretching vibration of alkyl ester), $1635 \mathrm{~cm}^{-1}$ (COO- antisymmetric stretching vibration of polygalacturonic acid), $1420 \mathrm{~cm}^{-1}$ (COO stretching, acids), $1240 \mathrm{~cm}^{-1}$ (C-O stretching) are characteristic for pectin, while the band at $1517 \mathrm{~cm}^{-1}$ is characteristic for lignin. The bands at $1147 \mathrm{~cm}^{-1}(\mathrm{O}-\mathrm{C}-\mathrm{O}$ asymmetric stretching glycosidic link) and $1071 \mathrm{~cm}^{-1}$ (C-O stretching, $\mathrm{C}-\mathrm{C}$ stretching) are typical for xyloglucan, and the band at $896 \mathrm{~cm}^{-1}$ is related to cellulose, hemicellulose and pectin.
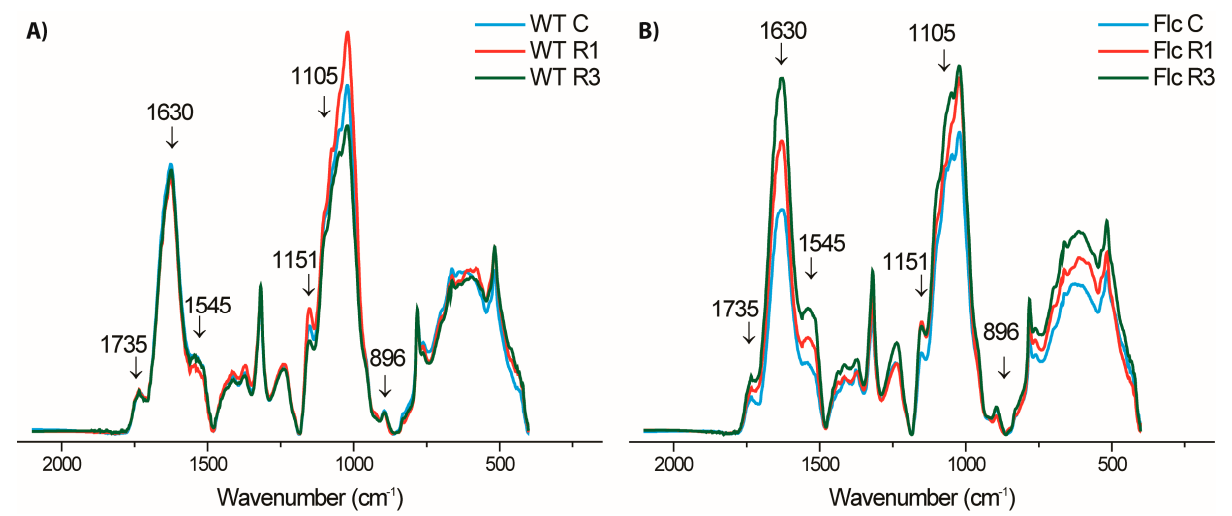

Figure 7. FTIR spectra of the cell walls of WT (A) and flacca (B) tomato leaves at the end of the experiment. $R_{1}$ represents plants exposed to the 1 st drought cycle and then optimally watered for the next 15 days. $R_{3}$ represents 3-days re-watered plants after the 3 rd drought cycle, while $C$ represents respective control plants.

The effect of prolonged recovery, and/or three drought cycles on the content of specific components of the cell wall in the WT and flacca mutant leaves of tomato obtained from the FTIR spectroscopy was analyzed using principal component analyses (PCA). PCA was applied on a spectral range $\left(800-1800 \mathrm{~cm}^{-1}\right)$ where the first principal component absorbs $72 \%$ of the total variance (PC1), while the second component (PC2) absorbs $25 \%$ (Figure 8). PC1 negatively correlates with the following wavenumbers at $1031 \mathrm{~cm}^{-1}$, $1098 \mathrm{~cm}^{-1}, 1239 \mathrm{~cm}^{-1}, 1321 \mathrm{~cm}^{-1}, 1533 \mathrm{~cm}^{-1}$ and $1635 \mathrm{~cm}^{-1}$. PC2 positively correlates with wavenumbers at $928 \mathrm{~cm}^{-1}, 1022 \mathrm{~cm}^{-1}, 1080 \mathrm{~cm}^{-1}$ and $1151 \mathrm{~cm}^{-1}$, and negatively correlates with wavenumbers at $1540 \mathrm{~cm}^{-1}$ and $1653 \mathrm{~cm}^{-1}$. Based on the values of scores and loadings in PC2 it can be seen that absorption bands characteristic for cellulose and xyloglucan polysaccharides are the most intensive in $W T R_{1}$ in comparison to $W T R_{3}$ and 
respective controls. On the other hand, intensities for the bands at 1540 and $1635 \mathrm{~cm}^{-1}$ (assigned to pectin and proteins) are negatively correlated with PC2. According to scores and loadings for PC1, bands characteristic for cellulose, pectin and lignin are the most pronounced in flacca $\mathrm{R}_{3}$ and less in flacca control plants. The results obtained demonstrate that plants after three drought episodes have elevated contents of cellulose, pectin and lignin compared to flacca plants after prolonged recovery and to corresponding controls. According to FTIR spectra analyses, the content of pectin in WT plants remains unchanged between control plants and plants with different drought history and recovery periods. However, in flacca plants, drought induced pectin accumulation, with the most prominent increase in plants after three drought cycles. On the other hand, in WT plants, the relative intensity of bands characteristic for cellulose and xyloglucan was the highest in plants after prolonged recovery. Additionally, the content of these polysaccharides was elevated in plants after three drought episodes compared to control plants. Contrarily, in flacca plants, three drought cycles caused the greatest accumulation of cellulose, hemicellulose and xyloglucan, while in the prolonged recovery a slight increase in their accumulation was observed in comparison to control plants.
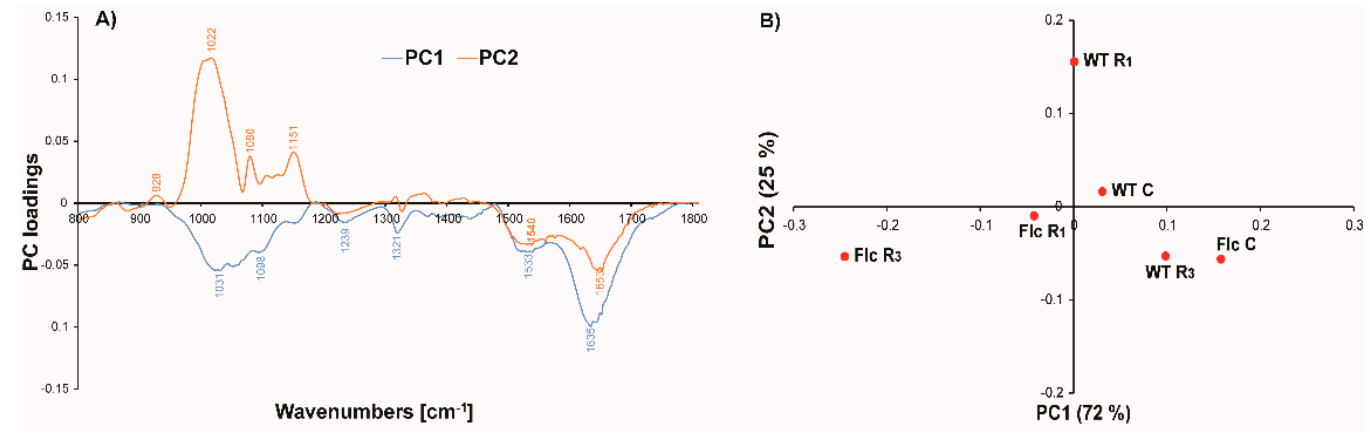

Figure 8. Graphical representation of (A) loadings and (B) scores for the first two PCs obtained using the spectral region $800-1800 \mathrm{~cm}^{-1}$ of tomato samples.

\section{Discussion}

\subsection{Low ABA Differences Result in flacca Traits}

ABA plays a pivotal role in regulating stomatal conductance and transpiration rate and, finally, in developing a plant's drought tolerance [52]. In our experiment, in comparison to the parental line, leaf ABA content in flacca is reduced by around $25 \%$ and exhibits a phenotype (smaller whole plants, shorter stems, decreased leaf area, opened stomata, wilted leaves) that is similar to other ABA-deficient tomato mutants described in the literature [49,53-59]. Numerous reports have shown that drought and recovery period affect ABA's status in tomato leaves [29,32,60].

Despite differences in constitutive ABA content, the exposure of plants to water deficit in all three drought cycles provoked ABA accumulation in both genotypes, though to a higher extent in WT (Figure 1). While the drought-induced ABA levels were restored during re-watering in WT in all cycles, in flacca a similar trend was observed only in the 2nd drought episode. We suppose that some form of ABA conjugates could dominate at that particular stage as a backup for potential upcoming drought [61].

The results obtained could be explained as an ABA-induced "after effect", as it could control stomatal conductance and transpiration rate in the early recovery phase [62]. This ABA-induced "after effect" could be considered as one of the safety mechanisms, which provides plants' fast recovery after drought stress [63,64].

Our result on the up-regulation of the NCED1 gene under water deprivation is in line with the observed ABA accumulation in tomato leaves (Figure 6). The up-regulation of NCEDs genes under drought has been demonstrated elsewhere $[61,62,65,66]$. We assume that the more pronounced expression of the NCED1 gene in WT observed in the 3rd drought cycle was mostly due to its de novo biosynthesis, while in the 1st and 2nd cycles 
the ABA was synthesized from its precursors and conjugates. It has been recently shown that, under stress conditions, ROS are involved also in non-enzymatic conversion of $\mathrm{ABA}$ precursors to $\mathrm{ABA}$, which might also contribute to the elevated ABA content in the ABA-deficient mutants $[67,68]$. However, ABA content and transcription intensity of the ABA-biosynthesis-related genes may not always be in correlation, as the level of ABA depends also on ABA's redistribution within the leaf and between root and shoot $[61,69,70]$.

Considering leaf water potential $\Psi$, the first drought cycle had a much greater impact on WT than on mutant plants, which is following a greater proline increase in WT compared to flacca mutant (Figures 3 and 4). Contrarily, in the 2nd and 3rd drought cycles, an opposite trend was observed in leaf water potential in flacca. Moreover, following every drought cycle, the differences in $\Psi$ between drought and recovery plants in both genotypes became smaller [71].

\subsection{Stomatal Sensitivity Increases with Exposure to Recurrent Drought}

Stomatal closure is the fastest physiological response among adaptive mechanisms that prevents water loss in plants under conditions of soil water limitation.

When WT tomato Ailsa Craig cv. plants were subjected to three drought cycles, a percentage of drought-inducible ABA content progressively decreased from the 1st to 3rd cycle (9-14\%), while stomata almost closed in the 3rd cycle $\left(g_{\mathrm{s}} 40 \mu \mathrm{molm}^{-2} \mathrm{~s}^{-1}\right)$. Under water deficit, though, stomata partly closed even in flacca, and transpiration rates were maintained higher in all three cycles in comparison to WT (two to five times higher $\mathrm{g}_{\mathrm{s}}$ in flacca). However, flacca's stomatal aperture was also the most responsive to water deficit in the 3rd cycle in spite of differences in gs between genotypes throughout the experiment (Figure 2). Stomatal closure is mainly determined by the ABA level as a part of chemical signaling [72,73] and, also by hydraulic factors, leaf water potential ( $\Psi)$ [74]. Both chemical and hydraulic drought-induced changes were the least in the 3rd cycle where the most efficient stomatal closure was observed. Similar trends in WT and flacca imply a possible role of an alternative mechanism that regulates stomata under a recurrent drought. We propose that exposure to a recurrent drought triggers the acquisition of stomatal sensitivity to $\mathrm{ABA}$ and $\Psi$, the alternative factor playing a role in the regulation of stomatal conductance and, thus, in stress memory. The results imply that the ABA level required to trigger efficient stomatal closure must exceed a certain threshold. We showed here a different relationship between ABA, $\Psi$ and stomatal conductance in WT and flacca, which implies a hydraulic regulative mechanism of stomatal closure to be preferential in flacca, opposite to the dominant ABA-dependent pathway revealed in WT (Figures 1-3). The drought-induced fall in leaf water potential in both WT and flacca was fully recovered only after the first drought episode, which, in the course of the experiment, progressively led to the establishment of new lower leaf potential. This is in line with recent studies on the effects of developmental and environmental factors on the ABA-acquired stomatal sensitivity in the rosette plant Arabidopsis, which showed that both factors, ontogenic stage of leaf and a relative humidity in the vicinity of a leaf, determined a differential stomatal sensitivity to ABA [75].

\subsection{Proline Accumulation Decreases with Repeating Drought Cycles}

The accumulation of osmolytes under drought is considered as a key protective mechanism against water stress in plant cells. In our previous work with the same tomato genotypes, we demonstrated that the extent of drought-induced accumulation of proline was similar in WT and flacca, irrespective of differences in their constitutive ABA levels [51]. However, when plants were grown under higher light intensity, drought induced more than three times higher accumulation of proline in WT than in flacca. The opposite trend was observed in sitiens tomato mutant where drought negatively affected proline content, while in WT plants proline content increased [76]. On the contrary, salt stress induced higher proline accumulation in sitiens compared to WT [56]. Higher proline accumulation under drought was recognized as one of the traits also noticed in tolerant wheat and 
Axonopus compressus grass cultivars in comparison to respective sensitive varieties [77,78]. Besides its widely accepted osmoprotective role, proline is also considered as one of the signaling molecules, and as a symptom of osmotic stress, rather than the adaptation process. Comparison of the dynamics of proline disappearance during the re-watering period in flacca (Figure 4) with the results from our previous paper performed under the same conditions except for growth light intensity influence [51], might indicate a role of light and photosynthesis in the drought-induced changes of proline metabolism [79].

In our experiment, we observed the most prominent proline accumulation in both genotypes in the 1st drought cycle, while after the 2nd and 3rd, plants developed weaker responses, with recovery to the control values within 3 days of re-watering. Similarly, Leufen and co-workers [80] obtained the same trend in proline accumulation in sugar beet exposed to recurrent drought. The opposite was observed in coffee and the baru tree with the largest increase in proline observed after the 3rd drought cycle [9,81]. While in WT $\Psi$ decreased to the same extent in all three cycles, in flacca, the reduction in $\Psi$ was significantly higher in the 2 nd and 3 rd drought cycles. As a progressive decrease in $\Psi$ was observed during re-watering in both genotypes, it can be concluded that the capacity of osmolyte accumulation was not enough to prevent a drought-induced decrease in leaf water potential during repeated drought cycles. Moreover, we observed no correlation between $\mathrm{ABA}$ and proline accumulation induced by drought that implied that the activation of proline biosynthesis was not an ABA-mediated response to drought as reported elsewhere [82-84]. As in our previous article, we here supposed the alternative role to osmoprotection of proline in drought, that is its involvement in cell wall stiffening [51,76]. Our hypothesis is that proline's role in cell wall fortification via (hydroxyl)proline-rich proteins, is controlled by light through the supply of carbohydrates from photosynthesis, and that low light production of photosynthates and hydroxycinnamates limits the cell wall formation and stiffening.

\subsection{Drought-Induced Oxidative Stress}

Drought-induced changes in the contents of the reduced or oxidized form of ascorbate indicate a disturbance in cellular redox homeostasis, which may be a result either of the activation of the ROS signaling pathway and accompanied antioxidative defense or the increased risk from oxidative damage due to the excessive accumulation of ROS [12]. Providing the ascorbate is the most abundant non-enzymatic antioxidant in the plant cell, and that its concentration is easily determined, it is often used in plant stress physiology studies to evaluate the extent of oxidative stress and antioxidative response [85]. However, the interpretation of stress-induced changes in a reduced or oxidized form of ascorbate is rather ambiguous due to the dual function of ROS [86,87]. In our study, drought induced the ascorbate oxidation only in flacca but not in WT, implicating a higher sensitivity of flacca to water deficit stress (Figure 5). A simultaneous stimulation of ascorbate biosynthesis in drought upon re-watering during the 2nd and 3rd cycle contributed to the higher redox state of ascorbate in mutants that experienced stress. Though the total ascorbate pool as well as the ascorbate redox state in leaves of both genotypes varied during plant development, a constitutively higher ascorbate content was observed in WT compared to flacca throughout the experiment. A constitutively higher ascorbate content was also observed in the Ailsa Craig cv. tomato cultivar compared to the flacca mutant [88]. On the other hand, notabilis tomato mutants in comparison to WT possess a similar ascorbate level [89], as well as abi4-insensitive Arabidopsis mutant [90]. Accordingly, the involvement of antioxidative metabolism in water stress memory was recently reported by Lukic et al. [25]. Authors reported that significantly increased levels of antioxidative enzymes under drought that remained elevated over weeks could be linked with better performances in plants subjected to upcoming stress.

Similarly, there are numerous studies reporting considerably elevated dehydroascorbate pull in stressed plants compared to controls, especially in drought-sensitive cultivars [14,91,92]. Sharma and Dubey [93] showed that mild and severe drought induced 
ascorbate decline in rice roots and shoots, which was accompanied by a decreased ascorbate redox state. Moreover, Hasanagić et al. [94] showed a decreased ascorbate accumulation in tomato due to prolonged drought, while DHA content remained unchanged until 28 days of water deprivation. These findings are also in line with results obtained in barley and rice where tolerant cultivars had a higher ascorbate content in comparison to sensitive cultivars $[14,95]$.

\subsection{Drought Differentially Affected Growth and Cell Wall Compounds Accumulation in Two Genotypes}

Growth parameters were evaluated at the end of the experiment, which enabled us to compare the effect of prolonged recovery and three drought cycles on biomass and leaf area. A decline in leaf area and the dry biomass of WT tomato plants was observed after three successive drought cycles but not after a single drought episode (Table 1). Similarly, Gomes and co-workers [96] showed that exposure to three drought cycles induced a growth inhibition. On the other hand, drought induced a doubled dry weight of leaves accompanied by a significant decrease in SLA in flacca. Our results are in line with the observed growth promotion of recovered plants of alfalfa and maize [97,98]. A smaller effect on growth promotion in flacca determined after three drought cycles compared to a prolonged recovery might be the result of shorter intermediate re-watering periods after the 2nd and 3rd drought episodes. One can suppose that an acclimation mechanism induced by drought involves the redistribution or overproduction of advantageous moieties such as sugars, organic acids and antioxidant compounds $[99,100]$. Similar biomass accumulation in recovered experiments suggests that flacca developed acclimation to drought stress by changing only morphological parameters. In this case, the elevated leaf area and dry leaf biomass were strengthened after a prolonged recovery in flacca, which implies the important role of a recovery period in the development of a specific plant memory as proposed by $\mathrm{Xu}$ and co-workers [101]. Such behavior was initiated during drought and established during the re-watering period.

As a major portion of the dry weight of plants comprises cell wall-derived compounds (approximately $50 \pm 5 \%$ ), we suppose that the drought-induced accumulation of dry biomass obtained in flacca is the result of the accumulated photosynthates and their allocation to the cell wall. Additionally, the accumulation of cell wall compounds would lead to leaf thickening, which could explain why flacca plants with a similar dry biomass possess different leaf areas and SLA (Table 1). Such morphological changes induced by drought positively affect photosynthetic efficiency due to tightly packing cells [102].

The stimulation of photosynthesis following drought and recovery has also been obtained in other species [98,101]. Alternatively, it has been suggested that the elevated photosynthesis and increased growth were related to restored stomatal conductance parameters compared to control values [101].

Drought-induced cell wall remodeling includes changes in architecture, accumulation, and cross-linking of cellulose and hemicelluloses-xyloglucan polymers [16], thus, cell wall modulation also contributes to drought tolerance development by maintaining the cell turgor and cell wall elasticity [103].

Based on the extensive comparison analysis of FTIR spectra of cell walls isolated from both genotypes (Figure 7), we further discuss the drought-induced changes of a differential abundance of cell wall constituents [104-110]. Consequently, a different drought history developed a diverse accumulation of cell wall compounds in both genotypes. In the case of WT leaves, the highest abundance of accumulated cellulose, hemicellulose and lignin was observed at the end of the recovery period after the 1st drought episode but not after three drought cycles (Figure 7). On the contrary, the most pronounced changes in the cell walls of flacca leaves were observed in recovered plants after three drought cycles. Cellulose, hemicellulose in total and xyloglucan, as a part of the most dominant hemicellulose polysaccharides, were significantly elevated in recovered plants after three drought cycles, as well as lignin polymers. Likewise, the most prominent changes in the cellulose-hemicellulose complex in WT were observed in recovered plants after one 
drought, while in flacca, this was noticed after three drought episodes. Drought-induced cellulose and hemicellulose accumulation contribute to maintaining cell turgor pressure and cell wall mechanical strength and rigidity, which supports cell protection from water deprivation and permitting their continuous growth [111,112].

Increased lignin deposition and up-regulation of enzymes related to its biosynthesis and accumulation under drought conditions were also reported in numerous articles [113-116]. In this way, lignin prevents water loss from the leaf, thus contributing to drought tolerance [116].

We also demonstrated the drought-induced biosynthesis of pectin, of which the content, as with other analyzed CW compounds, i.e., cellulose, hemicellulose and lignin, accumulated preferentially in flacca leaves after three drought cycles. Nonetheless, one and/or three drought episodes in WT plants did not influence pectin content, and it remained unchanged. With respect to water stress, the amount of side chains of pectic polymers significantly increased in drought tolerant cultivars [117]. Interestingly, there are many reports showing drought tolerant cultivars under drought stress accumulate higher amounts of pectin than susceptible cultivars. An increased pectin level in the cell wall from drought recovered plants in comparison to controls was observed in Nicotiana sylvestris $L$. and $H$. annuus leaves, respectively $[118,119]$. A higher amount of pectin after three drought episodes in recovery emphasizes their role as gelling agents and antidesiccants in maintaining cell wall hydration status during water deprivation [119].

The drought-induced cell wall thickening of water-conducting and supporting tissues [120] would contribute to more efficient turgor maintenance in otherwise wilting flacca plants. The tightening and loosening of cell walls accompanied by changes in the cell wall composition are processes tightly related to cell growth and regulated by various stresses [101]. Water stress certainly provoked cell wall component accumulation and additional cross-linking, which steers towards its fortification, preventing further transpiration and loss of water.

However, cell wall thickening presumably increasing with each subsequent drought cycle may create some kind of physiological memory and, consequently, plants' higher drought tolerance. Taken together, the accumulation of the aforementioned cell wall components being the most evident in flacca after three drought cycles implies that the drought acclimation mechanism was driven through morphological changes, and that prior drought cycles poorly contribute to drought tolerance; rather it is the duration of re-watering periods that are more important.

\section{Materials and Methods}

\subsection{Plant Material and Experimental Setup}

Wild type (WT) and flacca mutant tomato (Lycopersicon esculentum Mill. cv. Ailsa Craig) seeds were germinated in pots containing commercial substrate Klasman Potgrond $\mathrm{H}$. Following the phase of four developed leaves, plants were transferred to larger pots (a depth of $24 \mathrm{~cm}$ ). Plants were grown under controlled conditions with a light intensity of $250 \mu \mathrm{mol} \mathrm{m}{ }^{-2} \mathrm{~s}^{-1}$, photoperiod $14 / 10 \mathrm{~h}$ (day/night), day/night temperature of $26 / 17^{\circ} \mathrm{C}$, and $50 \%$ relative humidity. Volumetric soil water content (SWC) was continuously maintained at $38 \pm 2 \%$. In the phase of 6 leaves, plants from both genotypes were transferred to a light intensity of $800 \mu \mathrm{mol} \mathrm{m}{ }^{-2} \mathrm{~s}^{-1}$ with the same conditions of photoperiod, temperature, and humidity. After 4 days, plants (start) were divided into three groups. The first group was regularly irrigated during the whole experiment (control plants, C), the second was exposed to just one drought episode (D) and then optimally irrigated (R), while the third was subjected to three drought cycles (D) with recovery periods (R) of three days after each drought. Plants subjected to water deficit were not irrigated until reaching $11 \pm 2 \%$ moisture in the substrate. Recovered plants from all drought cycles achieved SWC of $38 \pm 2 \%$ immediately after the first day of the re-watering (Scheme 1 ). 


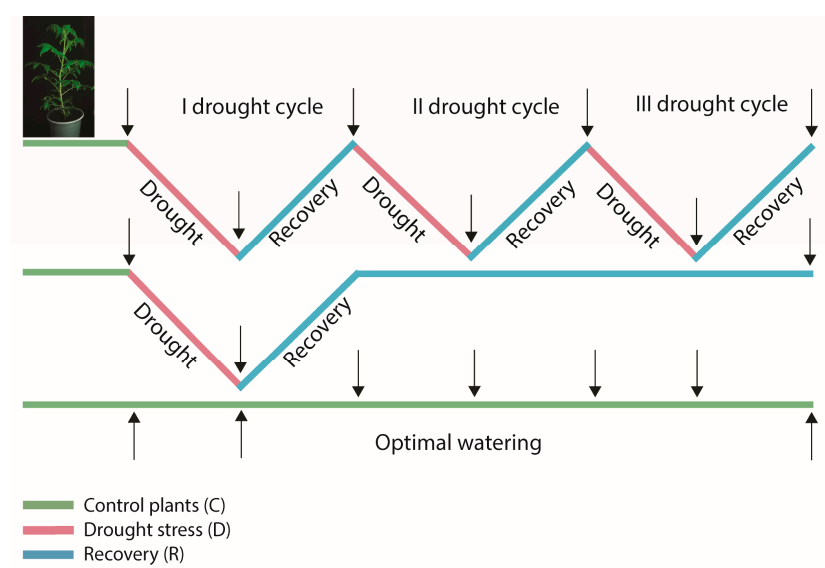

Scheme 1. Diagram of experimental design. Plants from both genotypes were submitted to repeated drought stress (red line), followed by recovery period (blue line). At the same time, set of plants were submitted to one drought episode (red lines) and then optimally watered (blue line). Control plants were optimally watered until the end of the experiment (green line).

For each treatment, four biological replicates of both genotypes were prepared. All of the samplings for biochemical measurements and measurements of stomatal conductance and relative water potential were performed using the fourth fully expanded leaf. Sampled leaves were immediately frozen in liquid nitrogen and stored at $-80^{\circ} \mathrm{C}$ for further analysis.

\subsection{Measurements of Morphological and Physiological Parameters}

Volumetric soil water content (SWC) was measured using the Theta probe (Delta-T, Cambridge, UK), and stomatal conductance $\left(\mathrm{g}_{\mathrm{s}}\right)$ was measured by porometer (AP4; Delta$\mathrm{T})$. Leaf water potential ( $\Psi, \mathrm{MPa}$ ) was carried out with a Scholander-type pressure bomb (Soil Moisture Equipment Corp., Santa Barbara, CA, USA). Fresh and dry weight of both, WT and flacca genotypes was determined upon all three drought episodes and after 3-days of recovery period, in treatment, as well as in control plants. Total leaf area (LA) was conducted by LI-3100 areameter (LI-COR, Lincoln, NE, USA), and specific leaf area was calculated using the equation: SLA = Leaf area/DW. All measurements were performed with four different plants per genotype and treatment.

\subsection{Extraction and Analysis of Abscisic Acid Content}

Determination of abscisic acid (ABA) content in the tomato leaves was performed as described in Živanović et al., 2020 [51]. ABA concentration was measured using indirect enzyme-linked immunosorbent assay (ELISA) with MAC 252 monoclonal antibody for ABA (John Innes Centre, Colney, Norwich, UK). Plate contents were measured at $405 \mathrm{~nm}$ by a microplate reader (Sunrise, Tecan, Switzerland).

\subsection{Determination of Leaf Proline Content}

In order to determine proline content, frozen leaf samples were homogenized in liquid nitrogen, extracted in $3 \%(w / v)$ sulfosalicylic acid and centrifuged at $14,000 \times g$ for $10 \mathrm{~min}$ at $4{ }^{\circ} \mathrm{C}$. The obtained supernatant was mixed with acidic ninhydrin and glacial acetic acid $(1: 1: 1, v / v / v)$ and incubated for $60 \mathrm{~min}$ on $100{ }^{\circ} \mathrm{C}$. The reaction mixture was placed on ice and extracted with toluene $(1: 1, v / v)$. The toluene fraction was used for determination of proline by measuring absorbance at $520 \mathrm{~nm}$, with toluene as blank [121].

\subsection{Determination of Total Leaf Ascorbate Content and Ascorbate Redox State}

The frozen leaf tissues were homogenized in 1.5\% meta-phosphoric acid with $2 \mathrm{mM}$ EDTA and centrifuged at $14,000 \times g$ for $8 \mathrm{~min}$ at $4{ }^{\circ} \mathrm{C}$. The reduced form of ascorbate was measured according to Morina et al. [122]. Briefly, ascorbate (Asc) concentration was determined as absorbance decreased at $265 \mathrm{~nm}$ after adding one unit of ascorbate 
oxidase (Sigma-Aldrich, Darmstadt, Germany) in the reaction mixture consisting of $300 \mathrm{mM}$ potassium phosphate buffer ( $\mathrm{pH}$ 5.5) and sample. Determination of the total ascorbate content was performed according to Vidovic et al. [123] with some modifications. In order to determine total Asc, the samples were diluted 8 times and incubated with $2.5 \mathrm{U}$ ascorbate oxidase in potassium phosphate buffer $(\mathrm{pH} 4.5)$ for 1 min to complete Asc oxidation. After that, reaction mixture was treated with potassium hydroxide to achieve $\mathrm{pH} 8$ and immediately derivatized with ortho-phenylenediamine (o-PDA) for 10 min in the dark. Reaction was stopped with $85 \% \mathrm{H}_{3} \mathrm{PO}_{4}$ and samples obtained were loaded on a reversedphase C18 column $(5.0 \mu \mathrm{m}, 250 \times 4.6 \mathrm{~mm}$ Luna C18 (2); Phenomenex Ltd., Torrance, CA, USA) using the Shimadzu LC-20AB Prominence liquid chromatography (Shimadzu, Kyoto, Japan). The elution gradient was formed with $20 \mathrm{mM}$ potassium phosphate buffer, $\mathrm{pH} 6.5$ (solvent A) and methanol (solvent B): 0-6 min, 30\% solution B (isocratic conditions); 6.00-6.01 min, 55\% solution B (isocratic conditions); $6.01-13.0 \mathrm{~min}, 55-30 \%$ solution B (linear gradient) at a flow rate of $0.8 \mathrm{mLmin}-1$. The fluorescence intensity of o-PDA-DHA derivative was measured at excitation and emission wavelengths of 360 and $430 \mathrm{~nm}$ using RF-10-AXL, fluorescence detector (Prominence, Shimadzu, Japan).

\subsection{RNA Isolation and Real Time PCR}

RNA was isolated by TRIzol ${ }^{\mathrm{TM}}$ Reagent (Invitrogene, Waltham, MA, USA) according to manufacturer's protocol. RNA was quantified with a NanoDrop spectrophotometer (IMPLENP300, Munich, Germany), and its quality was checked by electrophoresis on $1.5 \%$ agarose gel. To remove traces of DNA contamination, RNA was treated with DNase I (Thermo Fisher Scientific, Waltham, MA, USA) at $37{ }^{\circ} \mathrm{C}$ for $10 \mathrm{~min}$, according to the manufacturer's protocol. Synthesis of cDNAs from $1 \mu \mathrm{g}$ of total RNA was carried out in the reverse transcription reaction (RT), according to the manufacturer's protocol RevertAid First Strand cDNA Synthesis Kit (Thermo Scientific ${ }^{\mathrm{TM}}$, Waltham, MA, USA).

Expression of NCED1 gene, which is involved in abscisic acid biosynthesis, was evaluated by quantitative real time PCR using SYBR green in 7500 Real Time PCR System (Applied Biosystems, Waltham, MA, USA). A total of $10 \mu \mathrm{L}$ reaction mixture contained $1 \mu \mathrm{L}$ of RT reaction product, appropriate forward and reverse primers and Maxima SYBR Green/Rox qPCR Master Mix (Thermo Fisher Scientific, Waltham, MA, USA). The forward primer 5'AGGCAACAGTGAAACTTCCATCAAG3' and reverse primer 3'TCCATTAAAGA GGATATTACCGGGGAC5' ${ }^{\prime}$ were used for NCED1 amplification (GenBank ${ }^{\mathrm{TM}}$ Accession No. Z97215). Thermal cycling conditions for qRT-PCR included: initial denaturation on $95^{\circ} \mathrm{C}$, then 40 cycles of denaturation $\left(95^{\circ} \mathrm{C}\right.$ for $\left.30 \mathrm{~s}\right)$, annealing $\left(55^{\circ} \mathrm{C}\right.$ for $\left.30 \mathrm{~s}\right)$ and extension $\left(72{ }^{\circ} \mathrm{C}\right.$ for $\left.30 \mathrm{~s}\right)$. The absence of primer-dimer formation was checked in no-template controls. In an amplification reaction, the point in the cycle at which the target DNA has amplified enough so that its fluorescence reaches fixed threshold above the background fluorescence is called the $\mathrm{Ct}$ value of the sample. The expression level of the tested gene was normalized to the housekeeping gene actine and calculated relative to WT start control according to the $\Delta \Delta \mathrm{Ct}$ method. The results are presented as log2 transformation of fold changes $(\log 2 \mathrm{FC})$. For each sample, qRT-PCR was performed in triplicate [124].

\subsection{Cell Wall Isolation and Purification}

The plant cell wall was isolated according to the procedure described in SimonovićRadosavljević et al. [125]. The dried plant leaves were powdered with mortar and pestle and extracted in $80 \%$ methanol $(1 / 8, w / v)$ with shaking for $60 \mathrm{~min}$ at room temperature. The homogenate was centrifuged at $1000 \times g$ for $20 \mathrm{~min}$ at room temperature and pellet was washed two times with $80 \%$ methanol. The pellet was resuspended in $1 \mathrm{M} \mathrm{NaCl}$ with $0.5 \%$ Triton $\times 100$ and centrifuged at $1000 \times g$ for $20 \mathrm{~min}$ at room temperature. The pellet was re-washed with distilled water, once with absolute methanol and twice with acetone. The purified cell wall obtained was dried and additionally powdered in Mixer Mill MM 400 (Retsch) and further used for structural analyses. 


\subsection{FTIR Spectroscopy}

The Fourier-transform infrared (FTIR) spectra of the extracted cell wall materials were recorded using a Perkin Elmer Spectrum Two equipped with the Universal ATR accessory. The spectrum of each powder sample was collected in the range of $4000-400 \mathrm{~cm}^{-1}$ with 200 scans and a spectral resolution of $4 \mathrm{~cm}^{-1}$. Baseline correction was performed using the trial Spectra Gryph software (https://www.effemm2.de/spectragryph/index.html, accessed on 17 March 2021).

\subsection{Statistical Analysis}

Three-way ANOVA was used to reveal the effects of genotypes, number of drought cycles and water regimes and their interactions on $g_{s}, \psi$, morphological parameters, ABA, proline and ascorbate contents. Tukey post hoc test was used for specific comparisons among experimental groups and significance threshold value was set at $p \leq 0.05$.

Welch $\mathrm{t}$-test was used to determine differences in NCED1 gene expression. The experimental data processing was conducted using software package Statistica 8.0.

In order to investigate the similarities between the samples, principal component analyses (PCA) was performed on the FTIR spectra, in the region between 1800 and $800 \mathrm{~cm}^{-1}$ [126]. PCA decomposes the variation of matrix $\mathbf{X}$ into score matrix (T), loading matrix $(\mathbf{P})$ and residual matrix $(\mathbf{E}): \mathbf{T}=\mathbf{T} \mathbf{P}^{T}+\mathbf{E}$. The similarity of the samples can be visualized by reducing the dimensionality of the space, i.e., their projection on a subspace defined with a smaller number of dimensions (principal components). If the first two principal components absorb a sufficient percentage of the total variations, then the samples can be projected onto a plane spanned by the vectors of these principal components, which facilitates the visual identification of pattern similarities.

No preprocessing of data was required. The software Unscrambler X 10.4 (Camo Analytics, Oslo, Norway) was used for multivariate analysis.

\section{Conclusions}

In this work, we demonstrated that analyzed tomato genotypes (flacca mutant and its parental line Ailsa Craig cv.) developed different drought tolerant strategies depending on their constitutive ABA levels. A failure of the efficient stomatal closure mediated by drought-inducible $\mathrm{ABA}$ accompanied by lower leaf potential and transient oxidative stress are compensated by a double increase in the dry weight of flacca leaves in plants that experienced prolonged recovery. Drought induced more pronounced stomatal closure, ABA biosynthesis and proline accumulation in WT compared to the mutant, confirming the importance of stomata in water loss prevention in WT. The most efficient stomatal response observed in the 3rd drought cycle in WT, which did not correlate with ABA increase, implies that repeating drought cycles trigger the acquisition of stomatal sensitivity to a chemical and/or a hydraulic signal. On the other hand, the osmoprotective role of proline was not pertinent for developing drought stress memory, considering that the drought-induced accumulation of proline was dramatically decreased with repeating drought cycles.

We hypothesize that under certain conditions imposed by lower ABA content (flacca) and saturating, high growing light, modification of the cell wall occurred. Strengthening of the vascular tissue and cell wall capacity of water storage are traits favored by the enhancement of networking between cellulose, hemicellulose, pectin and hydroxyproline protein enrichment, and may present a target for future improvement of drought tolerance.

Supplementary Materials: The following are available online at https:/ /www.mdpi.com/article/10 .3390 / plants10112308/s1, Table S1: Statistical analysis of the results (three-way ANOVA) to test the influence of the treatment, number of drought cycles and two genotypes (WT and flacca), and their interactions on the amount of ABA, stomatal conductance $\left(g_{s}\right)$ and relative water potential $(\Psi)$ in tomato leaves; Table S2: Statistical analysis of the results (three-way ANOVA) to test the influence of the treatment, number of drought cycles and two genotypes (WT and flacca) and their interactions on the proline content, total ascorbate content and ascorbate redox state in tomato leaves. 
Author Contributions: Conceptualization, L.P. and S.V.J.; methodology, B.Ž., S.M.K. and L.P.; validation, S.M.K.; formal analysis, B.Ž., L.P., S.M.K., N.N. and D.M.; investigation, B.Ž., S.M.K., L.P., N.N. and D.M.; resources, S.V.J., data curation, L.P. and S.V.J.; writing-original draft preparation, B.Ž. and S.V.J., writing—review and editing, S.M.K., S.V.J., T.S., L.P. and N.N.; visualization, B.Ž., S.M.K., L.P. and D.M.; supervision, S.V.J., L.P. and T.S.; funding acquisition, S.V.J. All authors have read and agreed to the published version of the manuscript.

Funding: This work was funded by the Ministry of Education, Science and Technological Development, Republic of Serbia (Contract No. 451-03-68/2020-14/200053, Contract No. 451-03-68/202014/200116) and by the Centre for Green Technologies, University of Belgrade.

Acknowledgments: The authors are grateful to Ana Sedlarević Zorić and Jelena Dumanović for technical support.

Conflicts of Interest: The authors declare no conflict of interest.

\section{References}

1. Naumann, G.; Cammalleri, C.; Mentaschi, L.; Feyen, L. Increased economic drought impacts in Europe with anthropo-genic warming. Nat. Clim. Chang. 2021, 11, 485-491. [CrossRef]

2. Rojas, O. Agricultural extreme drought assessment at global level using the FAO-Agricultural Stress Index System (ASIS). Weather Clim. Extremes 2018, 27, 100184. [CrossRef]

3. Mafakheri, A.; Siosemardeh, A.; Bahramnejad, B.; Struik, P.; Sohrabi, Y. Effect of drought stress on yield, proline and chlorophyll contents in three chickpea cultivars. Aust. J. Crop Sci. 2010, 4, 580-585.

4. Pinheiro, C.; Chaves, M. Photosynthesis and drought: Can we make metabolic connections from available data? J. Exp. Bot. 2011, 62, 869-882. [CrossRef] [PubMed]

5. Wang, W.; Vinocur, B.; Altman, A. Plant responses to drought, salinity and extreme temperatures: Towards genetic engineering for stress tolerance. Planta 2003, 218, 1-14. [CrossRef] [PubMed]

6. Ashraf, M.; Foolad, M. Roles of glycine betaine and proline in improving plant abiotic stress resistance. Environ. Exp. Bot. 2007, 59, 206-216. [CrossRef]

7. Huseynova, I.M. Photosynthetic characteristics and enzymatic antioxidant capacity of leaves from wheat cultivars exposed to drought. Biochim. Biophys. Acta Bioenerg. 2012, 1817, 1516-1523. [CrossRef]

8. Kapoor, D.; Bhardwaj, S.; Landi, M.; Sharma, A.; Ramakrishnan, M.; Sharma, A. The impact of drought in plant metabolism: How to exploit tolerance mechanisms to increase crop production. Appl. Sci. 2020, 10, 5692. [CrossRef]

9. Menezes-Silva, P.E.; Sanglard, L.M.V.P.; Avila, R.; Morais, L.E.; Martins, S.C.V.; Nobres, P.; Patreze, C.M.; Ferreira, M.A.; Araújo, W.; Fernie, A.R.; et al. Photosynthetic and metabolic acclimation to repeated drought events play key roles in drought tolerance in coffee. J. Exp. Bot. 2017, 68, 4309-4322. [CrossRef] [PubMed]

10. Walter, J.; Jentsch, A.; Beierkuhnlein, C.; Kreyling, J. Ecological stress memory and cross stress tolerance in plants in the face of climate extremes. Environ. Exp. Bot. 2013, 94, 3-8. [CrossRef]

11. Xu, Z.; Zhou, G.; Shimizu, H. Plant responses to drought and rewatering. Plant Signal. Behav. 2010, 5, 649-654. [CrossRef] [PubMed]

12. Noctor, G.; Mhamdi, A.; Foyer, C. The Roles of Reactive Oxygen Metabolism in Drought: Not So Cut and Dried. Plant Physiol. 2014, 164, 1636-1648. [CrossRef] [PubMed]

13. Pyngrope, S.; Bhoomika, K.; Dubey, R. Reactive oxygen species, ascorbate-glutathione pool, and enzymes of their me-tabolism in drought-sensitive and tolerant indica rice (Oryza sativa L.) seedlings subjected to progressing levels of water deficit. Protoplasma 2013, 250, 585-600. [CrossRef] [PubMed]

14. Gruszka, D.; Janeczko, A.; Dziurka, M.; Pociecha, E.; Fodor, J. Non-enzymatic antioxidant accumulations in BR-deficient and BR-insensitive barley mutants under control and drought conditions. Physiol. Plant. 2017, 163, 155-169. [CrossRef] [PubMed]

15. Kesten, C.; Menna, A.; Sánchez-Rodríguez, C. Regulation of cellulose synthesis in response to stress. Curr. Opin. Plant Biol. 2017, 40, 106-113. [CrossRef] [PubMed]

16. Tenhaken, R. Cell wall remodeling under abiotic stress. Front. Plant Sci. 2015, 5, 771. [CrossRef] [PubMed]

17. Kwon, Y.; Kim, S.H.; Jung, M.S.; Kim, M.S.; Oh, J.E.; Ju, H.W.; Kim, K.i.; Vierling, E.; Lee, H.; Hong, S.W. Arabidopsis hot2 encodes an endochitinase-like protein that is essential for tolerance to heat, salt and drought stresses. Plant J. 2007, 49, 184-193. [CrossRef]

18. Wang, X.; Cai, X.; Xu, C.; Wang, Q.; Dai, S. Drought-Responsive Mechanisms in Plant Leaves Revealed by Proteomics. Int. J. Mol. Sci. 2016, 17, 1706. [CrossRef] [PubMed]

19. Zhang, S.-S.; Sun, L.; Dong, X.; Lu, S.-J.; Tian, W.; Liu, J.-X. Cellulose synthesis genes CESA6 and CSI1 are important for salt stress tolerance in Arabidopsis. J. Integr. Plant Biol. 2015, 58, 623-626. [CrossRef] [PubMed]

20. Abdallah, M.B.; Methenni, K.; Nouairi, I.; Zarrouk, M.; Youssef, N.B. Drought priming improves subsequent more severe drought in a drought-sensitive cultivar of olive cv. Chétoui. Sci. Horticult. 2017, 221, 43-52. [CrossRef] [PubMed]

21. Bruce, T.J.; Matthes, M.C.; Napier, J.A.; Pickett, J.A. Stressful "memories" of plants: Evidence and possible mechanisms. Plant Sci. 2007, 173, 603-608. [CrossRef] 
22. Fleta-Soriano, E.; Pinto-Marijuan, M.; Munné-Bosch, S. Evidence of Drought Stress Memory in the Facultative CAM, Apteniacordifolia: Possible Role of Phytohormones. PLoS ONE 2015, 10, e0135391. [CrossRef]

23. Tombesi, S.; Frioni, T.; Poni, S.; Palliotti, A. Effect of water stress "memory" on plant behavior during subsequent drought stress. Environ. Exp. Bot. 2018, 150, 106-114. [CrossRef]

24. Wang, X.; Mao, Z.; Zhang, J.; Hemat, M.; Huang, M.; Cai, J.; Zhou, Q.; Dai, T.; Jiang, D. Osmolyte accumulation plays important roles in the drought priming induced tolerance to post-anthesis drought stress in winter wheat (Triticum aestivum L.). Environ. Exp. Bot. 2019, 166, 103804. [CrossRef]

25. Lukić, N.; Kukavica, B.; Davidović-Plavšić, B.; Hasanagić, D.; Walter, J. Plant stress memory is linked to high levels of antioxidative enzymes over several weeks. Environ. Exp. Bot. 2020, 178, 104166. [CrossRef]

26. Sabir, N.; Singh, B. Protected cultivation of vegetables in global arena: A review. Indian J. Agric. Sci. 2013, 83, 123-135.

27. Food and Agriculture Organization. 2019. Available online: http://www.fao.org/faostat/en/\#home (accessed on 26 December 2019).

28. Živanović, B.; Vidović, M.; MilićKomić, S.; Jovanović, L.; Kolarž, P.; Morina, F.; Veljović Jovanović, S. Contents of phenolics and carotenoids in tomato grown under polytunnels with different UV-transmission rates. Turk. J. Agric. For. 2017, 41, 113-120. [CrossRef]

29. Tamburino, R.; Vitale, M.; Ruggiero, A.; Sassi, M.; Sannino, L.; Arena, S.; Costa, A.; Batelli, G.; Zambrano, N.; Scaloni, A.; et al. Chloroplast proteome response to drought stress and recovery in tomato (Solanum lycopersicum L.). BMC Plant Biol. 2017, 17, 1-14. [CrossRef] [PubMed]

30. Kumar Rai, G.; Parveen, A.; Jamwal, G.; Basu, U.; Ranjan Kumar, R.; Rai, P.K.; Sharma, J.P.; Alalawi, A.I.; Al-Duais, M.A.; Hossain, M.A.; et al. Leaf Proteome response to droughts and antioxidant potential in tomato (Solanum lycopersicum L.). Atmosphere 2021, $12,1021$.

31. Sant'Ana, D.V.P.; Lefsrud, M. Tomato proteomics: Tomato as a model for crop proteomics. Sci. Horticult. 2018, 239, 224-233. [CrossRef]

32. Iovieno, P.; Punzo, P.; Guida, G.; Mistretta, C.; van Oosten, M.J.; Nurcato, R.; Bostan, H.; Colatuono, C.; Costa, A.; Bagnaresi, P.; et al. Transcriptomic changes drive physiological responses to progressive drought stress and rehydration in tomato. Frontiers Plant Sci. 2016, 7, 371. [CrossRef] [PubMed]

33. Tuteja, N. Abscisic Acid and Abiotic Stress Signaling. Plant Signal. Behav. 2007, 2, 135-138. [CrossRef] [PubMed]

34. Vishwakarma, K.; Upadhyay, N.; Kumar, N.; Yadav, G.; Singh, J.; Mishra, R.K.; Kumar, V.; Verma, R.; Upadhyay, R.G.; Pandey, M.; et al. Abscisic Acid Signaling and Abiotic Stress Tolerance in Plants: A Review on Current Knowledge and Future Prospects. Front. Plant Sci. 2017, 8, 161. [CrossRef]

35. Wang, X.; Li, Q.; Xie, J.; Huang, M.; Cai, J.; Zhou, Q.; Dai, T.; Jiang, D. Abscisic acid and jasmonic acid are involved in drought priming-induced tolerance to drought in wheat. Crop. J. 2020, 9, 120-132. [CrossRef]

36. Li, P.; Yang, H.; Wang, L.; Liu, H.; Huo, H.; Zhang, C.; Liu, A.; Zhu, A.; Hu, J.; Lin, Y.; et al. Physiological and Transcriptome Analyses Reveal Short-Term Responses and Formation of Memory Under Drought Stress in Rice. Front. Genet. 2019, 10, 55. [CrossRef] [PubMed]

37. Sorrentino, G.; Haworth, M.; Wahbi, S.; Mahmood, T.; Zuomin, S.; Centritto, M. Abscisic Acid Induces Rapid Reductions in Mesophyll Conductance to Carbon Dioxide. PLoS ONE 2016, 11, e0148554. [CrossRef]

38. Kollist, H.; Nuhkat, M.; Roelfsema, M.R.G. Closing gaps: Linking elements that control stomatal movement. New Phytol. 2014, 203, 44-62. [CrossRef] [PubMed]

39. Ding, Y.; Fromm, M.E.; Avramova, Z. Multiple exposures to drought 'train' transcriptional responses in Arabidopsis. Nat. Commun. 2012, 3, 740. [CrossRef] [PubMed]

40. Godwin, J.; Farrona, S. Plant Epigenetic Stress Memory Induced by Drought: A Physiological and Molecular Perspective. Plant Epigenetics Epigenomics 2020, 2093, 243-259. [CrossRef]

41. Virlouvet, L.; Fromm, M. Physiological and transcriptional memory in guard cells during repetitive dehydration stress. New Phytol. 2014, 205, 596-607. [CrossRef] [PubMed]

42. Nambara, E.; Marion-Poll, A. Abscisic acid biosynthesis and catabolism. Annu. Rev. Plant Biol. 2005, 56, 165-185. [CrossRef]

43. Xiong, L.; Zhu, J.-K. Regulation of Abscisic Acid Biosynthesis. Plant Physiol. 2003, 133, 29-36. [CrossRef] [PubMed]

44. Hartung, W.; Wilkinson, S.; Davies, W.J. Factors that regulate abscisic acid concentrations at the primary site of action at the guard cell. J. Exp. Bot. 1998, 49, 361-367. [CrossRef]

45. Sagi, M.; Fluhr, R.; Lips, S.H. Aldehyde oxidase and xanthine dehydrogenase in a flacca tomato mutant with deficient abscisic acid and wilty phenotype. Plant Physiol. 1999, 120, 571-578.

46. Sagi, M.; Scazzocchio, C.; Fluhr, R. The absence of molybdenum cofactor sulfuration is the primary cause of the flacca phenotype in tomato plants. Plant J. 2002, 31, 305-317. [CrossRef]

47. Chen, G.; Shi, Q.; Lips, S.; Sagi, M. Comparison of growth of flacca and wild-type tomato grown under conditions diminishing their differences in stomatal control. Plant Sci. 2003, 164, 753-757. [CrossRef]

48. Cornish, K.; Zeevaart, J.A.D.; Cohn, M.A.; Butera, D.L.; Hughes, J.A. Phenotypic Expression of Wild-Type Tomato and Three Wilty Mutants in Relation to Abscisic Acid Accumulation in Roots and Leaflets of Reciprocal Grafts. Plant Physiol. 1988, 87, 190-194. [CrossRef] [PubMed] 
49. Imber, D.; Tal, M. Phenotypic Reversion of Flacca, a Wilty Mutant of Tomato, by Abscisic Acid. Science 1970, $169,592-593$. [CrossRef]

50. Taylor, I.B.; Tarr, A.R. Phenotypic interactions between abscisic acid deficient tomato mutants. Theor. Appl. Genet. 1984, 68, 115-119. [CrossRef] [PubMed]

51. Živanović, B.; MilićKomić, S.; Tosti, T.; Vidović, M.; Prokić, L.; VeljovićJovanović, S. Leaf soluble sugars and free amino acids as important components of abscisic acid-Mediated drought response in tomato. Plants 2020, 9, 1147. [CrossRef]

52. Lim, C.W.; Baek, W.; Jung, J.; Kim, J.-H.; Lee, S.C. Function of ABA in Stomatal Defense against Biotic and Drought Stresses. Int. J. Mol. Sci. 2015, 16, 15251-15270. [CrossRef]

53. Dodd, I.C.; Theobald, J.C.; Richer, S.K.; Davies, W.J. Partial phenotypic reversion of ABA-deficient flacca tomato (Solanum lycopersicum) scions by a wild-type rootstock: Normalizing shoot ethylene relations promotes leaf area but does not diminish whole plant transpiration rate. J. Exp. Bot. 2009, 60, 4029-4039. [CrossRef]

54. Fang, L.; Abdelhakim, L.; Hegelund, J.N.; Li, S.; Liu, J.; Peng, X.; Li, X.; Wei, Z.; Liu, F. ABA-mediated regulation of leaf and root hydraulic conductance in tomato grown at elevated $\mathrm{CO}_{2}$ is associated with altered gene expression of aquaporins. Hortic. Res. 2019, 6, 1-10. [CrossRef] [PubMed]

55. Ntatsi, G.; Savvas, D.; Huntenburg, K.; Druege, U.; Hincha, D.K.; Zuther, E.; Schwarz, D. A study on ABA involvement in the response of tomato to suboptimal root temperature using reciprocal grafts with notabilis, a null mutant in the ABA-biosynthesis gene LeNCED1. Environ. Exp. Bot. 2014, 97, 11-21. [CrossRef]

56. Poór, P.; Borbély, P.; Czékus, Z.; Takács, Z.; Ördög, A.; Popović, B.; Tari, I. Comparison of changes in water status and photosynthetic parameters in wild type and abscisic acid-deficient sitiens mutant of tomato (Solanum lycopersicum cv. RheinlandsRuhm) exposed to sublethal and lethal salt stress. J. Plant Physiol. 2018, 232, 130-140. [CrossRef] [PubMed]

57. Jones, H.; Sharp, C.S.; Higgs, K.H. Growth and Water Relations of Wilty Mutants of Tomato (Lycopersicon esculentum Mill.). J. Exp. Bot. 1987, 38, 1848-1856. [CrossRef]

58. Nagel, O.W.; Konings, H.; Lambers, H. Growth rate, plant development and water relations of the ABA-deficient tomato mutant sitiens. Physiol. Plant. 1994, 92, 102-108. [CrossRef]

59. Sharp, R.E. Interaction with ethylene: Changing views on the role of abscisic acid in root and shoot growth responses to water stress. Plant Cell Environ. 2002, 25, 211-222. [CrossRef]

60. Giorio, P.; Guida, G.; Mistretta, C.; Sellami, M.H.; Oliva, M.; Punzo, P.; Iovieno, P.; Arena, C.; de Maio, A.; Grillo, S.; et al. Physiological, biochemical and molecular responses to water stress and rehydration in Mediterranean adapted tomato landraces. Plant Biol. 2018, 20, 995-1004. [CrossRef] [PubMed]

61. Auler, P.A.; Amaral, M.N.D.; Rossatto, T.; Crizel, R.L.; Milech, C.; Chaves, F.C.; Souza, G.M.; Braga, E.J.B. Metabolism of abscisic acid in two contrasting rice genotypes submitted to recurrent water deficit. Physiol. Plant. 2020, 172, 304-316. [CrossRef] [PubMed]

62. Đurić, M.; Subotić, A.; Prokić, L.; Trifunović-Momčilov, M.; Cingel, A.; Vujičić, M.; Milošević, S. Morpho-physiological and molecular evaluation of drought and recovery in impatiens walleriana grown ex vitro. Plants 2020, 9, 1559. [CrossRef] [PubMed]

63. Dörffling, K.; Streich, J.; Kruse, W.; Muxfeldt, B. Abscisic acid and the after-effect of water stress on stomatal opening potential. Z. Pflanzenphysiologie 1977, 81, 43-56. [CrossRef]

64. Stålfelt, M.G. The Stomata as a Hydrophotic Regulator of the Water Deficit of the Plant. Physiol. Plant. 1955, 8, 572-593. [CrossRef]

65. Milosavljevic, A.; Prokic, L.; Marjanovic, M.; Stikic, R.; Sabovljevic, A. The effects of drought on the expression of TAO1, NCED and EIL1 genes and ABA content in tomato wild-type and flacca mutant. Arch. Biol. Sci. 2012, 64, 297-306. [CrossRef]

66. Muñoz-Espinoza, V.A.; López-Climent, M.F.; Casaretto, J.A.; Egomez-Cadenas, A. Water Stress Responses of Tomato Mutants Impaired in Hormone Biosynthesis Reveal Abscisic Acid, Jasmonic Acid and Salicylic Acid Interactions. Front. Plant Sci. 2015, 6 , 997. [CrossRef] [PubMed]

67. McAdam, E.L.; Brodribb, T.J.; McAdam, S.A. Does ozone increase ABA levels by non-enzymatic synthesis causing stomata to close? Plant Cell Environ. 2017, 40, 741-747. [CrossRef]

68. Postiglione, A.E.; Muday, G.K. The Role of ROS Homeostasis in ABA-Induced Guard Cell Signaling. Front. Plant Sci. 2020, 11, 968. [CrossRef] [PubMed]

69. Davies, W.J.; Kudoyarova, G.; Hartung, W. Long-distance ABA Signaling and Its Relation to Other Signaling Pathways in the Detection of Soil Drying and the Mediation of the Plant's Response to Drought. J. Plant Growth Regul. 2005, 24, 285-295. [CrossRef]

70. Hartung, W.; Sauter, A.; Hose, E. Abscisic acid in the xylem: Where does it come from, where does it go to? J. Exp. Bot. 2002, 53, 27-32. [CrossRef]

71. Yan, W.; Zheng, S.; Zhong, Y.; Shangguan, Z. Contrasting dynamics of leaf potential and gas exchange during progressive drought cycles and recovery in Amorph afruticosa and Robinia pseudoacacia. Sci. Rep. 2017, 7, 4470. [CrossRef] [PubMed]

72. Buckley, T.N. The control of stomata by water balance. New Phytol. 2005, 168, 275-292. [CrossRef] [PubMed]

73. Munemasa, S.; Hauser, F.; Park, J.; Waadt, R.; Brandt, B.; Schroeder, J.I. Mechanisms of abscisic acid-mediated control of stomatal aperture. Curr. Opin. Plant Biol. 2015, 28, 154-162. [CrossRef] [PubMed]

74. Henry, C.; John, G.P.; Pan, R.; Bartlett, M.K.; Fletcher, L.R.; Scoffoni, C.; Sack, L. A stomatal safety-efficiency trade-off constrains responses to leaf dehydration. Nat. Commun. 2019, 10, 1-9. [CrossRef] [PubMed]

75. Pantin, F.; Monnet, F.; Jannaud, D.; Costa, J.M.; Renaud, J.; Muller, B.; Simonneau, T.; Genty, B. The dual effect of abscisic acid on stomata. New Phytol. 2012, 197, 65-72. [CrossRef] [PubMed] 
76. Aroca, R.; Alguacil, M.D.M.; Vernieri, P.; Ruiz-Lozano, J.M. Plant Responses to Drought Stress and Exogenous ABA Application are Modulated Differently by Mycorrhization in Tomato and an ABA-deficient Mutant (Sitiens). Microb. Ecol. 2008, 56, 704-719. [CrossRef] [PubMed]

77. Nawaz, M.; Wang, Z. Abscisic Acid and Glycine Betaine Mediated Tolerance Mechanisms under Drought Stress and Recovery in Axonopuscompressus: A New Insight. Sci. Rep. 2020, 10, 1-10. [CrossRef] [PubMed]

78. Saeedipour, S. Relationship of Grain Yield, ABA and Proline Accumulation in Tolerant and Sensitive Wheat Cultivars as Affected by Water Stress. Proc. Natl. Acad. Sci. India Sect. B Biol. Sci. 2013, 83, 311-315. [CrossRef]

79. Ábrahám, E.; Rigó, G.; Székely, G.; Nagy, R.; Koncz, C.; Szabados, L. Light-dependent induction of proline biosynthesis by abscisic acid and salt stress is inhibited by brassinosteroid in Arabidopsis. Plant Mol. Biol. 2003, 51, 363-372. [CrossRef] [PubMed]

80. Leufen, G.; Noga, G.; Hunsche, M. Drought stress memory in sugar beet: Mismatch between biochemical and physio-logical parameters. J. Plant Growth Regul. 2016, 35, 680-689. [CrossRef]

81. Alves, R.D.F.B.; Menezes-Silva, P.E.; Sousa, L.F.; Loram-Lourenço, L.; Silva, M.L.F.; Almeida, S.E.S.; Silva, F.G.; de Souza, L.P.; Fernie, A.R.; Farnese, F.S. Evidence of drought memory in Dipteryxalata indicates differential acclimation of plants to savanna conditions. Sci. Rep. 2020, 10, 1-16. [CrossRef]

82. Sharma, S.; Villamor, J.G.; Verslues, P.E. Essential Role of Tissue-Specific Proline Synthesis and Catabolism in Growth and Redox Balance at Low Water Potential. Plant Physiol. 2011, 157, 292-304. [CrossRef] [PubMed]

83. Verslues, P.E.; Bray, E.A. Role of abscisic acid (ABA) and Arabidopsis thaliana ABA-insensitive loci in low water potential-induced ABA and proline accumulation. J. Exp. Bot. 2005, 57, 201-212. [CrossRef]

84. Yoshiba, Y.; Kiyosue, T.; Nakashima, K.; Yamaguchi-Shinozaki, K.; Shinozaki, K. Regulation of levels of proline as an osmolyte in plants under water stress. Plant Cell Physiol. 1997, 38, 1095-1102. [CrossRef] [PubMed]

85. Majer, P.; Vidović, M.; Czégény, G.; Jovanović, S.V.; Strid, Å.; Hideg, É. Evaluation of procedures for assessing anti-and pro-oxidants in plant samples. Anal. Methods 2016, 8, 5569-5580. [CrossRef]

86. Foyer, C.H.; Noctor, G. Ascorbate and Glutathione: The Heart of the Redox Hub. Plant Physiol. 2011, 155, 2-18. [CrossRef] [PubMed]

87. Hideg, É.; Jansen, M.A.; Strid, Å. UV-B exposure, ROS, and stress: Inseparable companions or loosely linked associates? Trends Plant Sci. 2013, 18, 107-115. [CrossRef]

88. Petrović, I.; Jovanović, Z.; Stikić, R.; Marjanović, M.; Savić, S. Influence of severe drought on leaf response in ABA contrasting tomato genotypes (wild type and flacca Mutant). Biol. Life Sci. Forum 2021, 4, 96. [CrossRef]

89. Li, X.; Ahammed, G.J.; Zhang, Y.Q.; Zhang, G.Q.; Sun, Z.H.; Zhou, J.; Zhou, Y.H.; Xia, X.J.; Yu, J.Q.; Shi, K. Carbon dioxide enrichment alleviates heat stress by improving cellular redox homeostasis through an ABA-independent process in tomato plants. Plant Biol. 2014, 17, 81-89. [CrossRef] [PubMed]

90. Zhang, Z.-W.; Wu, Z.-L.; Feng, L.-Y.; Dong, L.-H.; Song, A.-J.; Yuan, M.; Chen, Y.-E.; Zeng, J.; Chen, G.-D.; Yuan, S. MgProtoporphyrin IX Signals Enhance Plant's Tolerance to Cold Stress. Front. Plant Sci. 2016, 7, 1545. [CrossRef]

91. Zhang, C.; Shi, S.; Liu, Z.; Yang, F.; Yin, G. Drought tolerance in alfalfa (Medicago sativa L.) varieties is associated with enhanced antioxidative protection and declined lipid peroxidation. J. Plant Physiol. 2018, 232, 226-240. [CrossRef]

92. Iyer, N.J.; Tang, Y.; Mahalingam, R. Physiological, biochemical and molecular responses to a combination of drought and ozone in Medicagotruncatula. Plant Cell Environ. 2012, 36, 706-720. [CrossRef]

93. Sharma, P.; Dubey, R.S. Drought Induces Oxidative Stress and Enhances the Activities of Antioxidant Enzymes in Growing Rice Seedlings. Plant Growth Regul. 2005, 46, 209-221. [CrossRef]

94. Hasanagić, D.; Koleška, I.; Kojić, D.; Vlaisavljević, S.; Janjić, N.; Kukavica, B. Long term drought effects on tomato leaves: Anatomical, gas exchange and antioxidant modifications. Acta Physiol. Plant. 2020, 42, 1-14. [CrossRef]

95. Chawla, S.; Jain, S.; Jain, V. Salinity induced oxidative stress and antioxidant system in salt-tolerant and salt-sensitive cultivars of rice (Oryza sativa L.). J. Plant Biochem. Biotechnol. 2012, 22, 27-34. [CrossRef]

96. Gomes, F.P.; Oliva, M.A.; Mielke, M.S.; Almeida, A.-A.F.; Aquino, L.A. Osmotic adjustment, proline accumulation and cell membrane stability in leaves of Cocos nucifera submitted to drought stress. Sci. Hortic. 2010, 126, 379-384. [CrossRef]

97. Erice, G.; Louahlia, S.; Irigoyen, J.J.; Sánchez-Díaz, M.; Avice, J.-C. Biomass partitioning, morphology and water status of four alfalfa genotypes submitted to progressive drought and subsequent recovery. J. Plant Physiol. 2010, 167, 114-120. [CrossRef]

98. Sun, C.; Gao, X.; Chen, X.; Fu, J.; Zhang, Y. Metabolic and growth responses of maize to successive drought and rewatering cycles. Agric. Water Manag. 2016, 172, 62-73. [CrossRef]

99. Chen, D.; Wang, S.; Xiong, B.; Cao, B.; Deng, X. Carbon/Nitrogen Imbalance Associated with Drought-Induced Leaf Senescence in Sorghum bicolor. PLoS ONE 2015, 10, e0137026. [CrossRef] [PubMed]

100. Rosa, M.; Prado, C.; Podazza, G.; Interdonato, R.; González, J.A.; Hilal, M.; Prado, F.E. Soluble sugars. Plant Signal. Behav. 2009, 4, 388-393. [CrossRef] [PubMed]

101. Xu, Z.; Zhou, G.; Shimizu, H. Are plant growth and photosynthesis limited by pre-drought following rewatering in grass? J. Exp. Bot. 2009, 60, 3737-3749. [CrossRef] [PubMed]

102. Wellstein, C.; Poschlod, P.; Gohlke, A.; Chelli, S.; Campetella, G.; Rosbakh, S.; Canullo, R.; Kreyling, J.; Jentsch, A.; Beierkuhnlein, C. Effects of extreme drought on specific leaf area of grassland species: A meta-analysis of experimental studies in temperate and sub-Mediterranean systems. Glob. Chang. Biol. 2017, 23, 2473-2481. [CrossRef] 
103. Moore, J.P.; Vicré-Gibouin, M.; Farrant, J.; Driouich, A. Adaptations of higher plant cell walls to water loss: Drought vs. desiccation. Physiol. Plant. 2008, 134, 237-245. [CrossRef]

104. Kačuráková, M.; Smith, A.C.; Gidley, M.J.; Wilson, R.H. Molecular interactions in bacterial cellulose composites studied by 1D FT-IR and dynamic 2D FT-IR spectroscopy. Carbohydr. Res. 2002, 337, 1145-1153. [CrossRef]

105. Kalisz, G.; Gieroba, B.; Chrobak, O.; Suchora, M.; Starosta, A.; Sroka-Bartnicka, A. Vibrational Spectroscopic Analyses and Imaging of the Early Middle Ages Hemp BastFibres Recovered from Lake Sediments. Molecules 2021, 26, 1314. [CrossRef]

106. Liang, C.Y.; Marchessault, R.H. Infrared spectra of crystalline polysaccharides: II Native celluloses in the region from 640 to $1700 \mathrm{~cm}^{-1}$. J. Polym. Sci. 1959, 39, 269-278. [CrossRef]

107. Marchessault, R.H. Application of infra-red spectroscopy to cellulose and wood polysaccharides. Pure Appl. Chem. 1962, 5, 107-130. [CrossRef]

108. Simonović, J.; Stevanic, J.; Djikanović, D.; Salmén, L.; Radotić, K. Anisotropy of cell wall polymers in branches of hardwood and softwood: A polarized FTIR study. Cellulose 2011, 18, 1433-1440. [CrossRef]

109. Stewart, D. Fourier Transform Infrared Microspectroscopy of Plant Tissues. Appl. Spectrosc. 1996, 50, 357-365. [CrossRef]

110. Szymanska-Chargot, M.; Zdunek, A. Use of FT-IR Spectra and PCA to the Bulk Characterization of Cell Wall Residues of Fruits and Vegetables along a Fraction Process. Food Biophys. 2012, 8, 29-42. [CrossRef]

111. Le Gall, H.; Philippe, F.; Domon, J.-M.; Gillet, F.; Pelloux, J.; Rayon, C. Cell Wall Metabolism in Response to Abiotic Stress. Plants 2015, 4, 112-166. [CrossRef] [PubMed]

112. Roig-Oliver, M.; Bresta, P.; Nadal, M.; Liakopoulos, G.; Nikolopoulos, D.; Karabourniotis, G.; Bota, J.; Flexas, J. Cell wall composition and thickness affect mesophyll conductance to $\mathrm{CO}_{2}$ diffusion in Helianthus annuus under water deprivation. J. Exp. Bot. 2020, 71, 7198-7209. [CrossRef] [PubMed]

113. Andrade, L.M.; Peixoto-Junior, R.F.; Ribeiro, R.V.; Nobile, P.; Brito, M.S.; Marchiori, P.E.; Carlin, S.D.; Martins, A.P.B.; Goldman, M.H.S.; Llerena, J.P.P.; et al. Biomass Accumulation and Cell Wall Structure of Rice Plants Overexpressing a Dirigent-Jacalin of Sugarcane (ShDJ) Under Varying Conditions of Water Availability. Front. Plant Sci. 2019, 10, 65. [CrossRef] [PubMed]

114. Gu, H.; Wang, Y.; Xie, H.; Qiu, C.; Zhang, S.; Xiao, J.; Li, H.; Chen, L.; Li, X.; Ding, Z. Drought stress triggers proteomic changes involving lignin, flavonoids and fatty acids in tea plants. Sci. Rep. 2020, 10,1-11. [CrossRef]

115. Jiang, Y.; Yao, Y.; Wang, Y. Physiological Response, Cell Wall Components, and Gene Expression of Switchgrass under Short-Term Drought Stress and Recovery. Crop Sci. 2012, 52, 2718-2727. [CrossRef]

116. Li, T.; Huang, Y.; Khadr, A.; Wang, Y.-H.; Xu, Z.-S.; Xiong, A.-S. DcDREB1A, a DREB-binding transcription factor from Daucus carota, enhances drought tolerance in transgenic Arabidopsis thaliana and modulates lignin levels by regulating lignin-biosynthesis-related genes. Environ. Exp. Bot. 2019, 169, 103896. [CrossRef]

117. Leucci, M.R.; Lenucci, M.S.; Piro, G.; Dalessandro, G. Water stress and cell wall polysaccharides in the apical root zone of wheat cultivars varying in drought tolerance. J. Plant Physiol. 2008, 165, 1168-1180. [CrossRef] [PubMed]

118. Clemente-Moreno, M.J.; Gago, J.; Díaz-Vivancos, P.; Bernal, A.; Miedes, E.; Bresta, P.; Liakopoulos, G.; Fernie, A.R.; Hernández, J.A.; Flexas, J. The apoplastic antioxidant system and altered cell wall dynamics influence mesophyll conductance and the rate of photosynthesis. Plant J. 2019, 99, 1031-1046. [CrossRef] [PubMed]

119. Roig-Oliver, M.; Nadal, M.; Clemente-Moreno, M.J.; Bota, J.; Flexas, J. Cell wall components regulate photosynthesis and leaf water relations of Vitis vinifera cv. Grenache acclimated to contrasting environmental conditions. J. Plant Physiol. 2019, 244, 153084. [CrossRef] [PubMed]

120. Chen, K.-M.; Wang, F.; Wang, Y.-H.; Chen, T.; Hu, Y.-X.; Lin, J.-X. Anatomical and chemical characteristics of foliar vascular bundles in four reed ecotypes adapted to different habitats. Flora 2006, 201, 555-569. [CrossRef]

121. Bates, L.S.; Waldren, R.P.; Teare, I.D. Rapid determination of free proline for water-stress studies. Plant Soil 1973, $39,205-207$. [CrossRef]

122. Morina, F.; Jovanović, L.; Mojović, M.; Vidovic, M.; Pankovic, D.; Jovanovic, S.V. Zinc-induced oxidative stress in Verbascumthapsus L. is caused by an accumulation of reactive oxygen species and quinhydrone in the cell wall. Physiol. Plant. 2010, 140, 209-224. [CrossRef] [PubMed]

123. Vidović, M.; Morina, F.; Milić, S.; Albert, A.; Zechmann, B.; Tosti, T.; Winkler, J.B.; Jovanović, S.V. Carbon allocation from source to sink leaf tissue in relation to flavonoid biosynthesis in variegated Pelargonium zonale under UV-B radiation and high PAR intensity. Plant Physiol. Biochem. 2015, 93, 44-55. [CrossRef]

124. Livak, K.J.; Schmittgen, T.D. Analysis of relative gene expression data using real-time quantitative PCR and the $2^{-\Delta \Delta C T}$ method. Methods 2001, 25, 402-408. [CrossRef] [PubMed]

125. Simonović-Radosavljević, J.; Pristov, J.B.; Mitrović, A.L.; Steinbach, G.; Mouille, G.; Tufegdžić, S.; Maksimović, V.; Mutavdžić, D.; Janošević, D.; Vuković, M. Parenchyma cell wall structure in twining stem of Dioscorea balcanica. Cellulose 2017, 24, 4653-4669.

126. Bro, R.; Smilde, A.K. Principal component analysis. Anal. Methods 2014, 6, 2812-2831. [CrossRef] 